\title{
Geological, Soil and Sediment Studies in Chelsaton Sedimentary Basin, Kabul, Afghanistan
}

\author{
Hafizullah Rasouli ${ }^{1}$, Abdul Ghias Safi ${ }^{2}$ \\ ${ }^{1}$ Department of Geology, Geoscience Faculty, Kabul University, Kabul, Afghanistan \\ ${ }^{2}$ Department of Hydrometeorology, Geoscience Faculty, Kabul University, Kabul, Afghanistan \\ Email: hafizullah.rasouli133@gmail.com
}

How to cite this paper: Rasouli, H. and Safi, A.G. (2021) Geological, Soil and Sediment Studies in Chelsaton Sedimentary Basin, Kabul, Afghanistan. International Journal of Geosciences, 12, 170-193. https://doi.org/10.4236/ijg.2021.122011

Received: March 7, 2020

Accepted: February 23, 2021

Published: February 26, 2021

Copyright $\odot 2021$ by author(s) and Scientific Research Publishing Inc. This work is licensed under the Creative Commons Attribution International License (CC BY 4.0).

http://creativecommons.org/licenses/by/4.0/

\section{(c) (i) Open Access}

\begin{abstract}
The geology, sediment and soil studies are important due to its significant impacts on agriculture, mining, constructions materials, industries, environment, ground water percolation, air pollution, surface and ground water pollutions, earthquakes and geo-hazards in Afghanistan. In this research, we studied petrography, Sediment, tectonic structures, soil fraction selection by using hydrometer, sieving analysis, and geological mapping. Results show different kinds of metamorphic rocks of low grade and medium grade metamorphisms, Garnete mica Schist, Garnete Schist, Quarsite, different types of minerals among rocks. Further, type of sediment consisting residual angular (Autochthonous) and rounded (Allochthonous) transported by water, among sediments consisting Garnete, Gneiss, Schist, Quarsite, Biotite and consisting different type of sizes boulders, Cobble, Granule, Sand, Silt. Hydrometer analysis shows different types of soil clayey loam, sandy loam, silty loam. Moreover, Geological mapping shows complex tectonic structures like joints, cracks, faults, folds, anticline and syncline. The obtained results suggest that the petrography, sediments and soil researches can be used efficiently for catchments of the Kabul Basin and other basins in Afghanistan.
\end{abstract}

\section{Keywords}

Rock Types, Geological Mapping, Pedogenic Horizons, Sediments, Tectonic, Faults, Folds, Fracture, Joints, Minerals, Sieving Analyses, Hydrometer, Inter Mountains Backing Basins

\section{Introduction}

The Chelsaton sedimentary basin is located at the southeast side of Kabul which 
covered an area of $132.5 \mathrm{Km}^{2}$ [1] [2]. In this basin, all regolith and sediments are transported from different points of Loger, Asmayey mountains by sudden floods and Kabul River were accumulated at the different thickness in different locations of this basin. The Chelsaton Basin belongs to Quaternary (Pleistocene) and Neogen geological periods, different sediments are deposited after one another and forms of morphology, which we can see at the different reliefs [3]. Types of sediments in this basin directly belong the kinds of rocks located in surrounding mountains. In these sediments, we can see Garnete, Biotite and Muscovite minerals particles. The surrounding mountains of this basin is formed from metamorphic rocks like Schist, Gneiss, Slate it's called Crystalline of Kabul and it belongs to Precambrian (20 - 40 million years ago). The Chelsaton Mountains are series of Loger Mountain range and it is located from Southwest to Northeast which is called walayati and khengal series [4] [5]. In these mountains we can seen different mining of rocks like slate, Gneisses, Garnets mica schist and gravels for constructions materials [6] [7]. When the gravel analysis was done, there was more than Quartzite, Gneisses and Schist between these sediments. The morphology of Chelsaton belongs to three kinds of relief, it consists of high (upper course), belongs to mountains slops, middle relief (middle course) belongs to hills and plains areas (lower course), it belongs to agricultural lands and the Chelsaton Basin is located between mountains ranges which is called inter mountains backing basin. In addition, in plain areas passing Kabul River and its two laterals located agricultural lands [8] [9].

The main aim of this study is to choose geological and Pedogenic characteristics, used for selection different types of rock, sediment fractions and soil types in the context of significant impacts on agriculture, mining, constructions materials, industries, environment, ground water percolation, air pollution, surface, ground water pollutions, earthquakes and geo-hazards in Afghanistan [10] [11]. This is complicated due to the different types of metamorphic rocks, minerals, sediments and the dynamic response of weathering and exogenic forces [12]. The thickness, sizes of soil and sediment vary with year-to-year variation in hydro-meteorological conditions of the basin. Therefore, geological and Pedogenic researches for the future become most useful in efficient management and planning of geology and soil. This research is therefore essential to study the petrography, different sizes of river sediments and soil, with no or scarce previous research in this basin. The main aim of this study is to briefly research on the geology, sediment and soil in the Chelsaton basin in Afghanistan [13].

\section{Methods and Materials}

In this research, we study geology, sediments, Pedogenic horizons and geological mapping of Chelsaton sedimentary basin to find out different types of rocks, mineral, sediments, soil type by using sieving and hydrometer analysis in the study of basin, as it requires laboratory works. Thus, for the study of rocks we transported rock, sediment and soil samples to the laboratory and used thin sec- 
tions, for sediments study in laboratory. So, we used sieving analysis and gravel analysis methods. For soil study we used stove for drying soil samples at $150^{\circ} \mathrm{C}$, after we sieved soil sample from $2 \mathrm{~mm}$ and by hydrometer to find soil fraction percentage of sand, silt and clay which is called fine fractions and used 12 classis of soils in triangle, the geological mapping by geological instruments like compass, tape recorder, hummer, lenses.

\section{Study Area}

This study is carried out on Chelsaton Sedimentary Basin (Figure 1 and Figure 2) which is also a sub-basin of Kabul River Basin. It is located in southeast side of Kabul City, on Loger Mountain range in Afghanistan. Its total area is reached to $132.5 \mathrm{~km}^{2}$ [14].

\section{Result and Discussion}

The Chelsaton Basin sediments belong to Quaternary (Pleistocene) [15]. Sediments carried from Paghman, Loger, Asmayie, Qorugh and Paghman mountains range. These mountains are located at the surrounded Chelsaton sedimentary basin and locked like inter mountains backing basin. Sediments carried by flooding and Kabul river, at the different periods of time and made different thickness, and accumulated different types of minerals of metamorphic rocks

\section{GEOLOGICAL SETTING OF STUDY AREA}

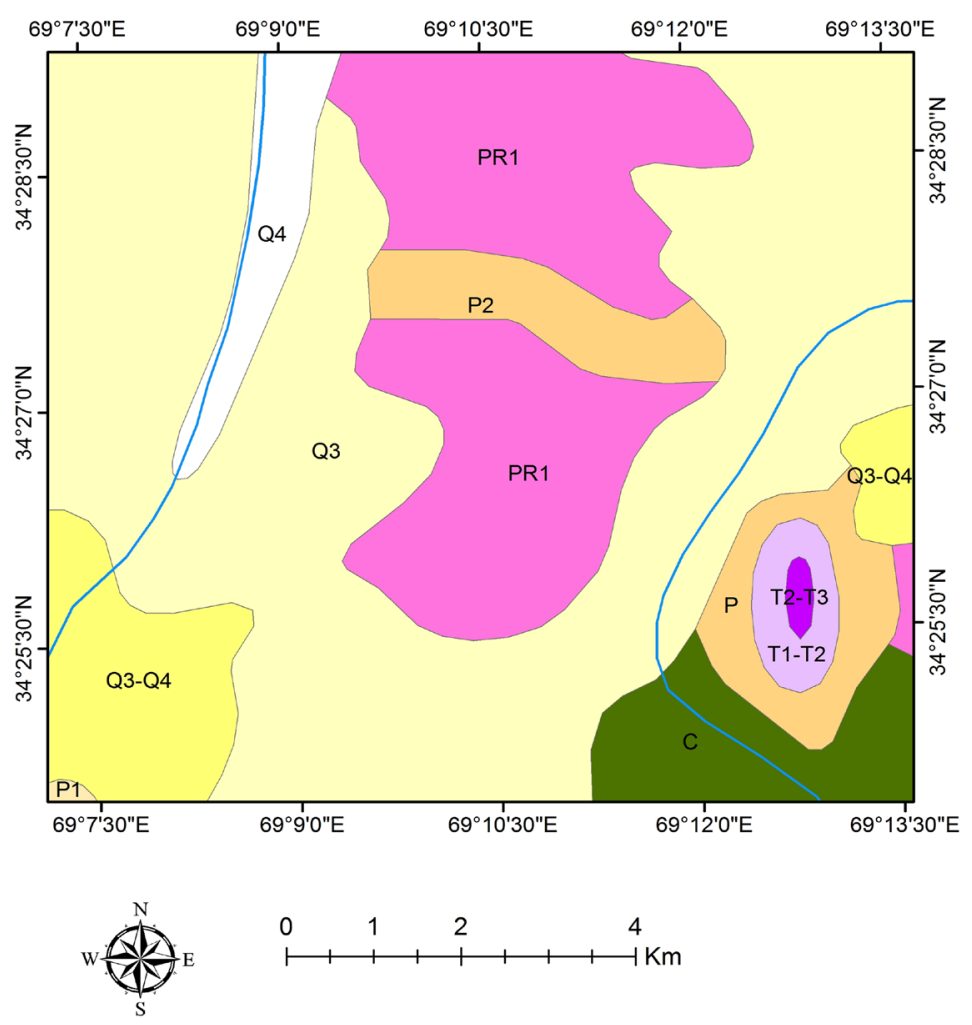

\section{Legend}

Q4 Recent, conglomerate and sandstone

Q3-Q4 Late Quaternary and Recent, fan alluvium and colluvium

Q3 Late Quaternary, loess

Q2 Middle Quaternary, conglomerate and sandstone

P2 Eocene, ultramafic intrusions

P1 Pliocene. Undifferentiated, conglomerate and sandstone

T2-T3 Middle Triassic-Late Triassic, sandstone and siltstone

T1-T2 Early Triassic-Middle Triassic, limestone and dolomite

P Late Permian, limestone and dolomite

C Vendian complex-Cambrian, limestone and dolomite

PR1 Early Proterozoic, gneiss

river

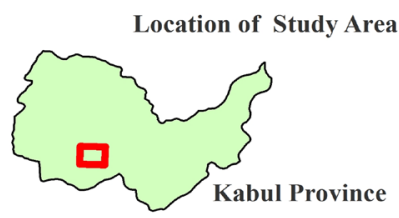

Figure 1. Stratigraphy of different rocks in Chelsaton sedimentary basin, Kabul, Afghanistan. 


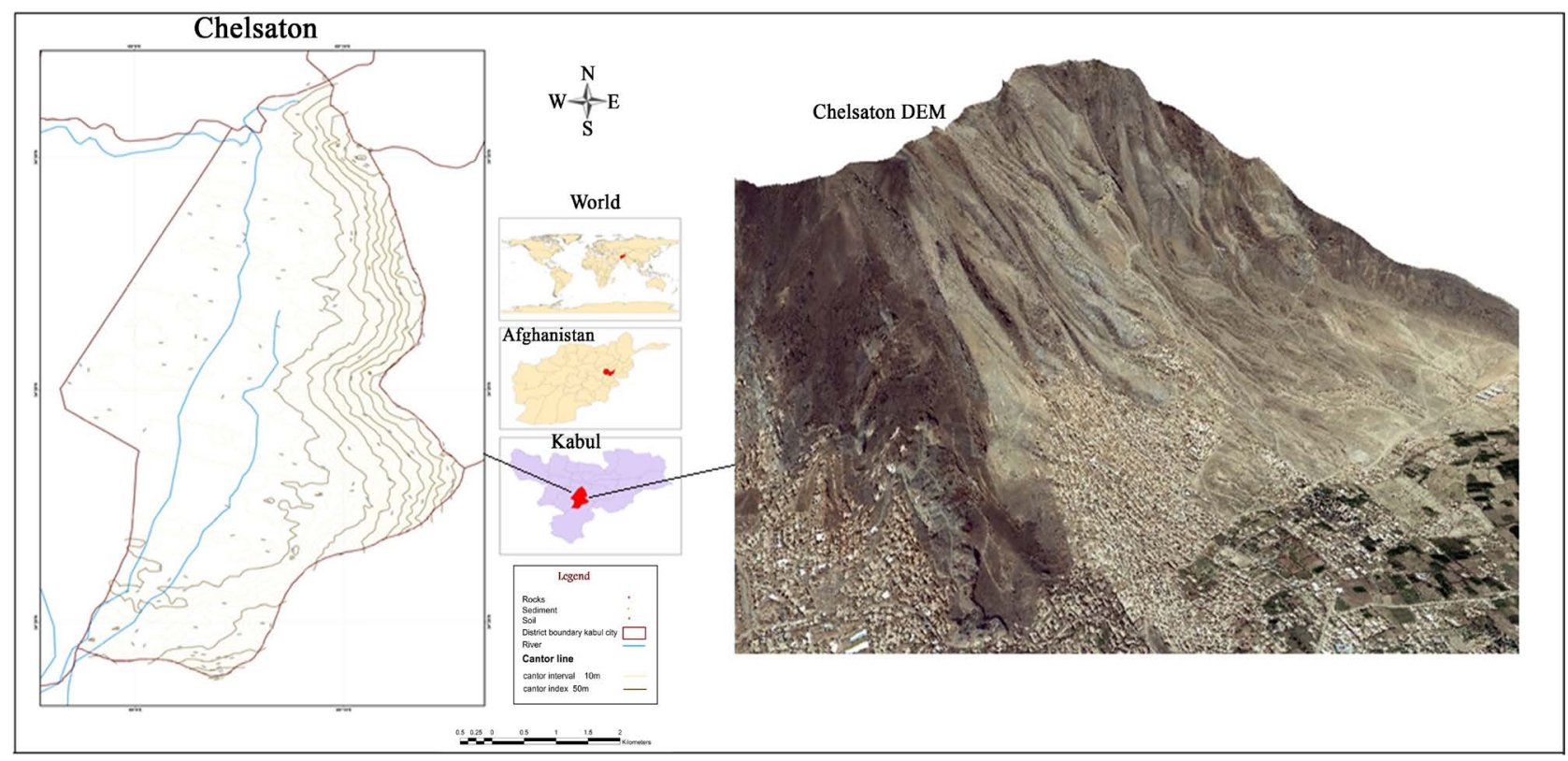

Figure 2. Location map of Chelsaton sedimentary basin, Kabul, Afghanistan.

like Garnete, Biotite and Muscovite. These minerals belong to mother rocks that are located at the surrounding mountains areas of Chelsaton. In this research, we focus on the study of petrography, sediment, tectonic structures, and soil fraction selection by using hydrometer, sieving analysis, and geological mapping. Findings of this research show different kind of metamorphic rocks of low grade and medium grade metamorphisms, Garnete mica Schist, Garnete Schist, Quarsite, different types of minerals among rocks like Garnete, micas. Types of sediment consisting residual angular and rounded transported by water, among sediments consisting Garnete, Gneisses, Schist, Quarsite, Biotite that consist dissimilar type of sizes borders, Cobble, Granule, Sand, Silt. Soil types are clayey loam, sandy loam and silty loam.

\section{Geology of Kabul}

First of all, I would like to generally give brief information about the geology of Kabul Basin.

Kabul Basin belongs to Quaternary (Pleistocene) period, [16]. Sediments carried from Paghman, Aliabad, Asmayie, Qorugh and Logger mountains. These mountains are located at the surrounded areas of Kabul Basin and these sediments carried by water at the diverse periods of time and made different thickness. The upper and middle parts of Kabul Basin terraces and there accumulated some heavy and light minerals and these minerals belonging to mother rocks that located at the surrounding mountains areas of Kabul Basin. For example, Epidote, Kyanite and Granite we can find in some terraces of Kabul River Basin because these belong to all Metamorphic rocks (Crystalline). It is located at the surrounding mountains of Kabul Basin. Also, there are some others minerals like Rutile and Zircon which belong to igneous rocks of Pagh- 
man Mountains range [17]. In addition, there is some others minerals like Muscovite and Biotite, they are also belong to all metamorphic rocks and are located in the surrounding mountains of Kabul Basin. As well as, Biotite and Rutile minerals in middle and lower terraces of Paghman River belong to igneous rocks of Paghman Mountain range and all sediments carried by water and accumulated to one another in terraces [18]. All rivers of Kabul Basin joined at the different locations and all running about from west to east, and sediments of Kabul Basin belong to Tertiary (Eocene and Oligocene), the age of sediments between upper and middle parts of Kabul is about (20 - 45) millions years which is called Tertiary formations [19]. Upper part of these sediments covered by younger sediments of lower Quaternary (Pleistocene) sediments, it consists of the terraces above. It has different complex, altitudes and locations. For example, upper part of Kabul River Basin belongs to Quaternary and there we can see more consolidated and unconsolidated gravels sediments, but middle part of Kabul River Basin belongs to Tertiary. There is some unconsolidated sands, Marls (gray, white, green and brown) colors, and upper part of these sediments covered by rivers terraces [20]. All mountains surrounding of Kabul Province, made by metamorphic rocks, without Paghman Mountains in adaption metamorphic rocks, it is made by some igneous rocks also, other all mountain made from metamorphic rocks, from Radiometry method they find the life time of these mountains about $(928 \pm 8)$ million years [21]. The older one is located at the Khair Khana Mountains and the younger is in Shawaky and Qorugh mountains range [22].

\section{Rock Studies in Chelsaton Basin}

All surrounding mountains of Kabul Sedimentary Basin are metamorphic rocks like Slate, Schist and Gneiss is called crystalline but we can find Granite only in Paghman.

In this research, we studied one part of Kabul Basin (Chelsaton), there is different kind of metamorphic rocks Gneiss, schist's, like low grade and medium grade metamorphism Garnete mica schist, Garnete Schist, Quarsite. So, in these we found different type of minerals Garnete, micas (Figure 3). All surrounding mountains belong to Precambrian (20 - 45 million years ago) [23].

\section{Study of Sediments (Angular Sediments)}

All sediments transported by flooding and water belong to the surrounding mountains and it relates to physical weathering Authochtoneouse and angular because it is not transported by long space and its taluses and accumulated in mountains slops. When we done the gravel analysis method there was biggest size of $40 \mathrm{Cm}=$ Cobble, Medium size $5 \mathrm{Cm}=$ Granule, Small size $2 \mathrm{~mm}=$ Sand and Smallest size $>1 \mathrm{~mm}=$ Silt, between these sizes we found different types of rocks and minerals particles like Garnete, Gneiss, Quarsite and Schist's, Slates, Mica, Biotite (Figure 4). 

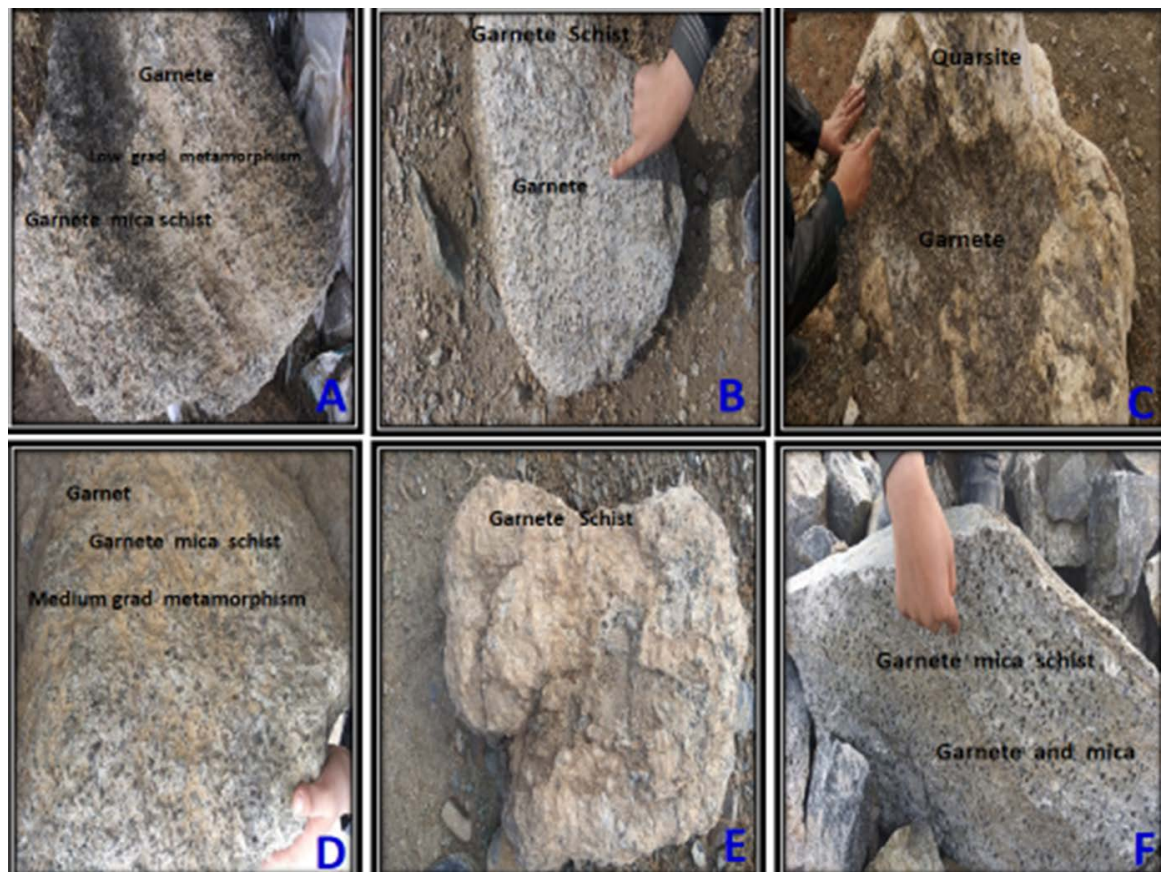

Figure 3. Different types of rocks in Chelsaton Sedimentary Basin (A) Garnete mica schist belong to low grade metamorphism, (B) Garnete schist, (C) Quarsite, (D) Garnete mica schist and it belongs to medium grade metamorphism,(E) Garnete schist, (F) Garnet mica schist.

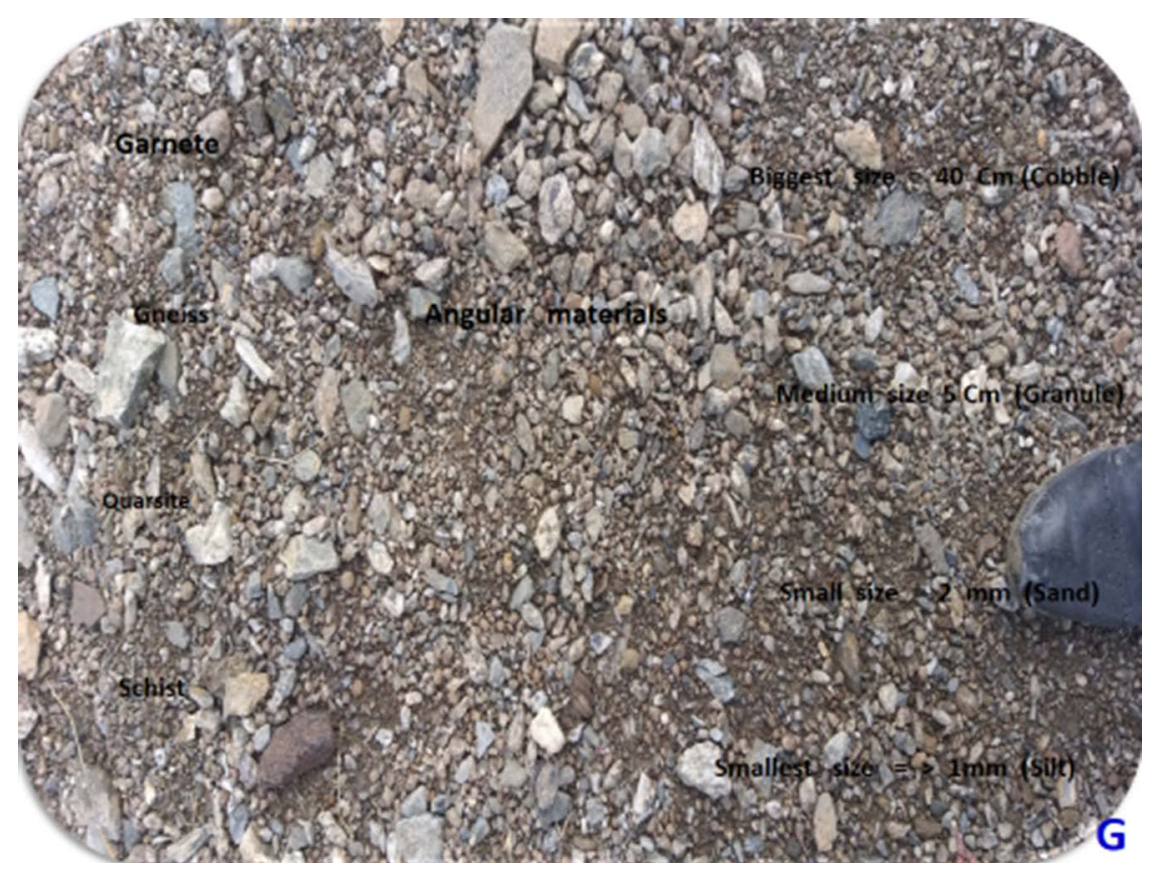

Figure 4. Angular sediments in Chelsaton sedimentary basin.

\section{Sediments Studies (Rounded Sediments)}

These related to those sediments transported through long distance by water during the snow melting seasons. Its form of imbrication and layers showed the direction of water in the ancient times. In these sediments we found different 


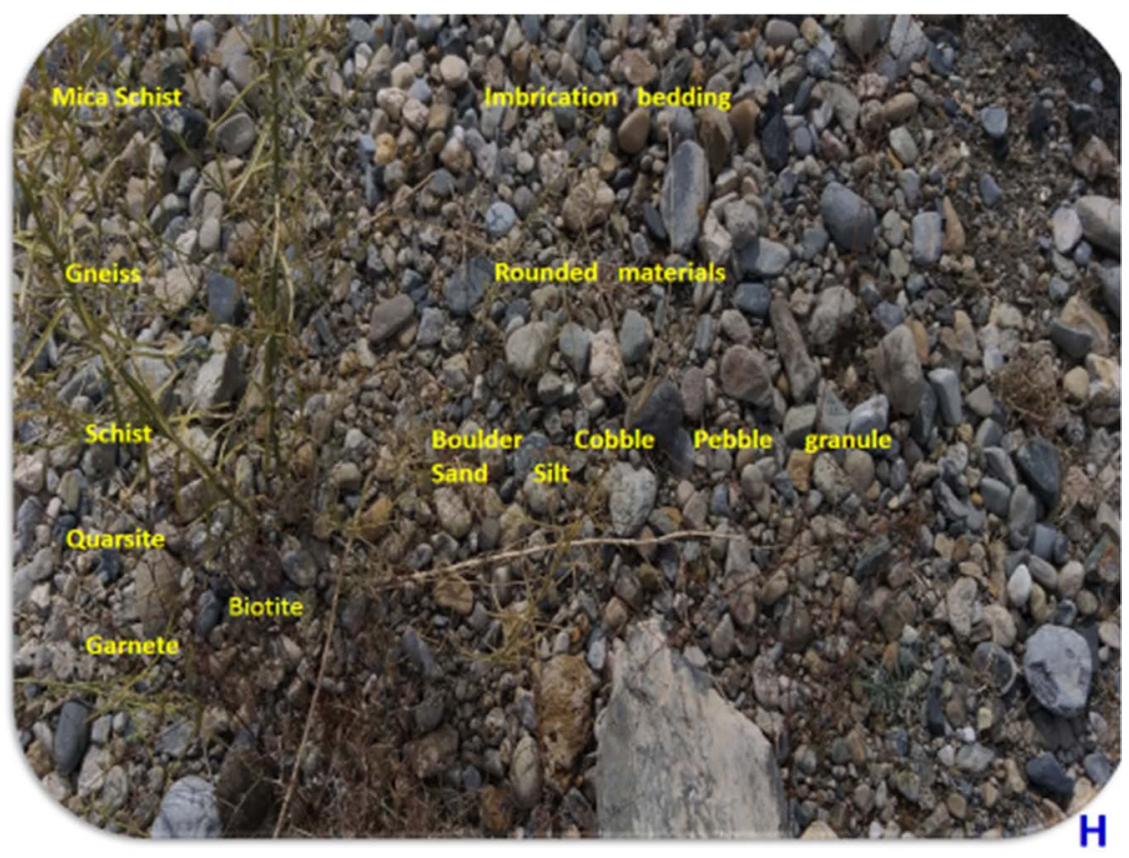

Figure 5. Types of roundness sediments in Chelsaton.

type of borders, Cobbles, pebbles, granules, Sands (course, medium, fine), silts (Course and fine). Between these sizes we found dissimilar types of rocks and minerals particles like Garnete, Gneiss, Quarsite and Schist's, Slates, Mica, Biotite. The roundness belongs to the hardness of rocks and minerals like Gneisses little rounded (Figure 5).

\section{Alluvial Fan and Soil Erosion}

As all know Afghanistan is one of the countries that has the arid and semi-arid climate. All mountains are barred and there is no any vegetation's covers. At the flooding seasons precipitation make different types of soil erosion at the land surface different types of runoff and gully or rain rills [24] and eroded at the different thickness and made different types of alluvial fans and alluvial approns.

\section{Sediments Sizes Changing}

Chelsaton Sedimentary Basin is one of the inter mountain backing basins. The size of sediments in this basin belongs to the near and away from mountains range [25]. When we get near to the mountains the sizes of sediment are getting bigger and angular, and when the distance far from mountains range the sizes of sediments are getting smaller and angular as we see in (Figure 6). At the near part of mountains we can found Boulder, Cobble, Pebble, granule but in lower and plain areas we can see fine materials like sand, silt and clay.

\section{Terraces in Chelsaton Basin}

In this basin general dry river flows that belongs to the flooding and snow melting seasons. In this basin we can find different types of terraces. In these terraces 


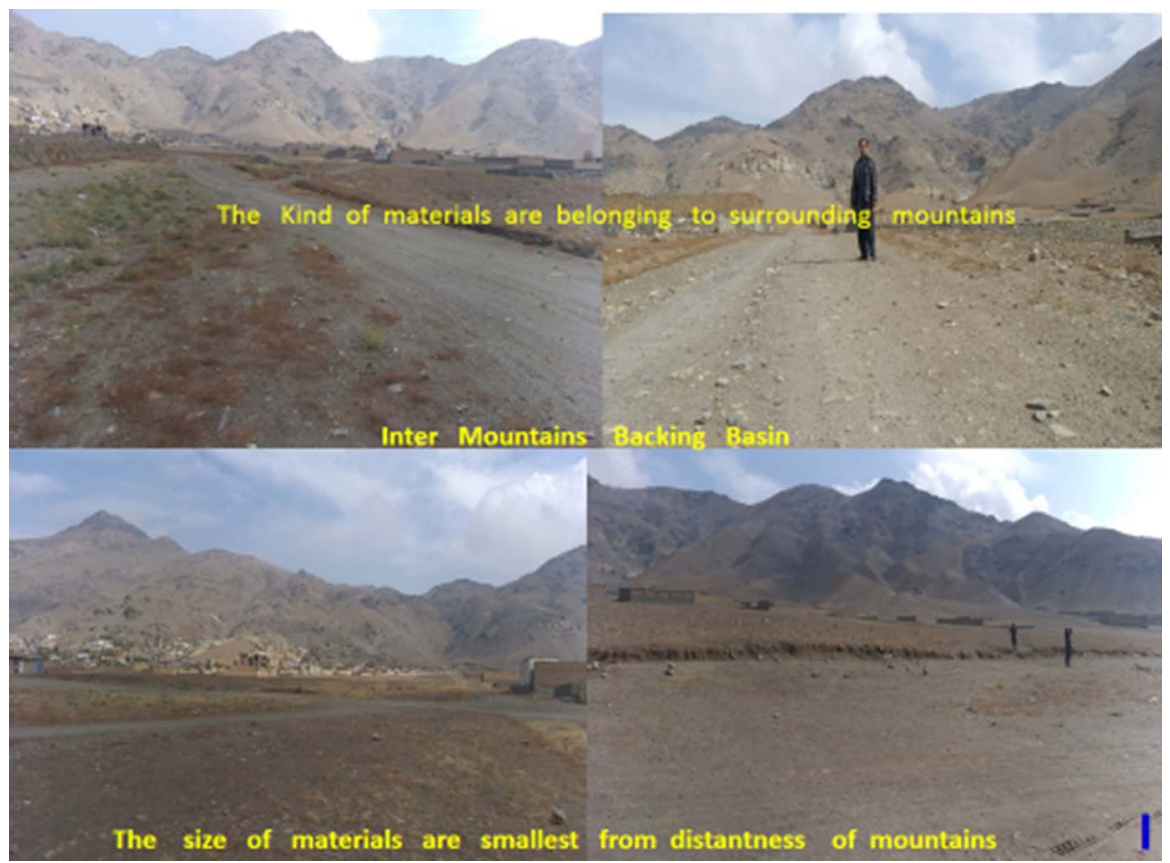

Figure 6. Sizes changing of sediments in Chelsaton.

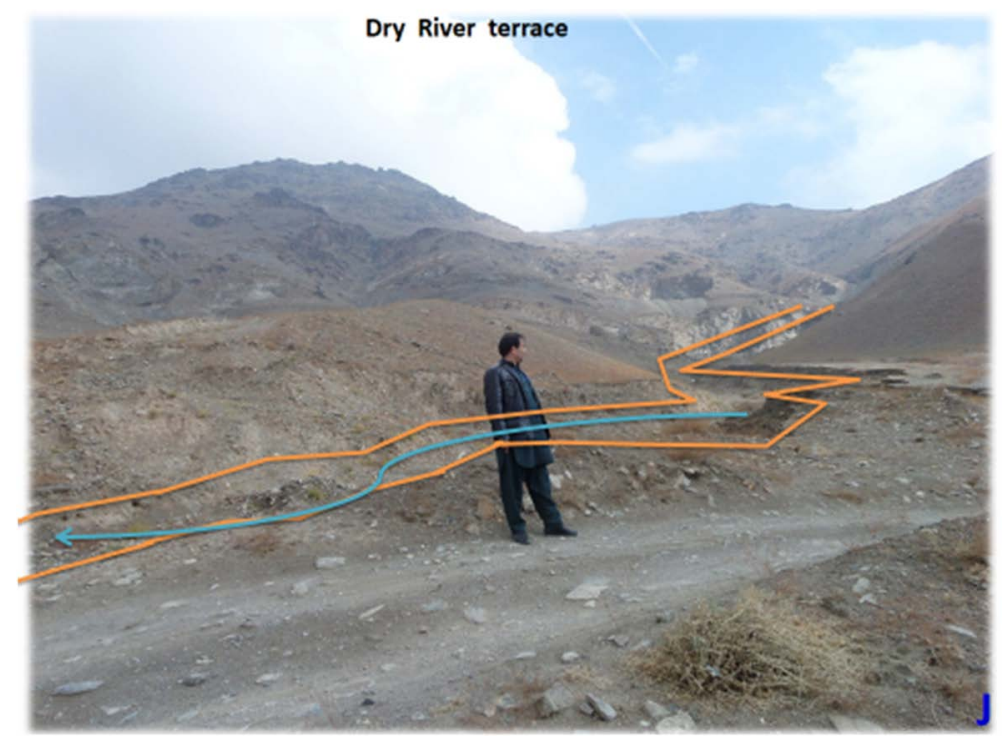

Figure 7. Dry river terraces in Chelsaton.

we can find different types of sediments like bolder, cobble, pebbles, granules, sands and silts. These sizes belong to the slope and velocity of river, at the upper course we can see bigger sizes and the middle course we can see middle sizes and at the lower course we can see smaller sizes (Figure 7).

\section{Valleys in Chelsaton}

In the mountains areas we can find different types of valleys, but in this basin some places are $\mathrm{V}$-shape valleys. Because, in the mountain slopes, there are more down cutting and bed of the valley more eroded and in the slopes little wea- 
thered laterals (Figure 8).

\section{Study of Soil Profiles}

In this research, we study three terraces (I, II and III). Profile I and II for hydrometer analysis and profile three sieving analysis method.

\section{Profile I}

In this profile we can find different type of layers and there is different types of sizes, soil type and soil structures. According to Hydrometer analysis, the soil type in this profile is clayey loam. There are different types of gravels like bolder, cobble, pebble, granule, sand, silt and clay. Also, there are crumbling and worm abstract structures (Figure 9).

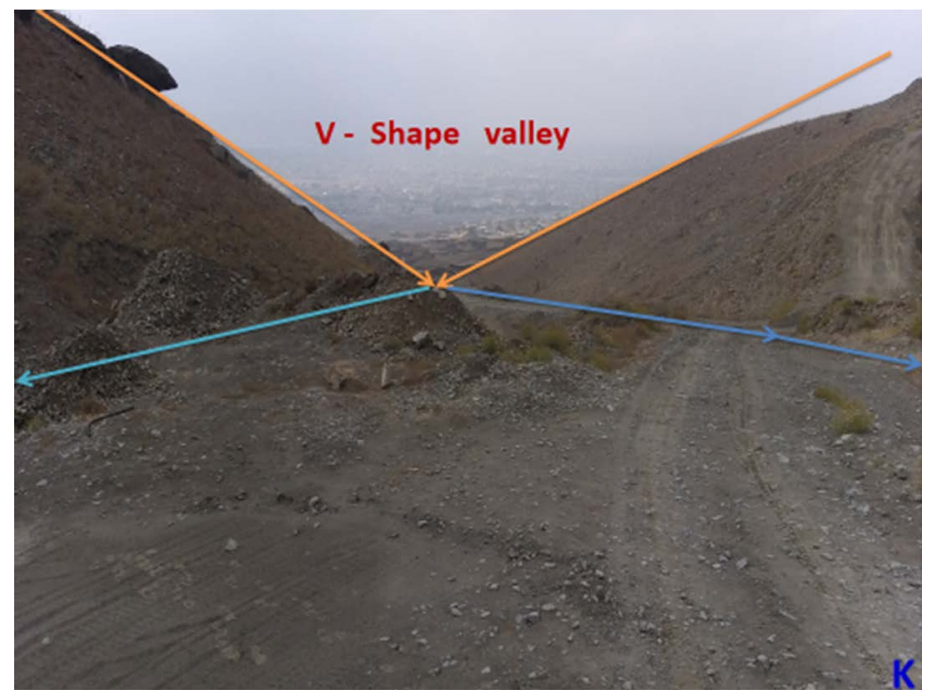

Figure 8. V-shape valley in Chelsaton.

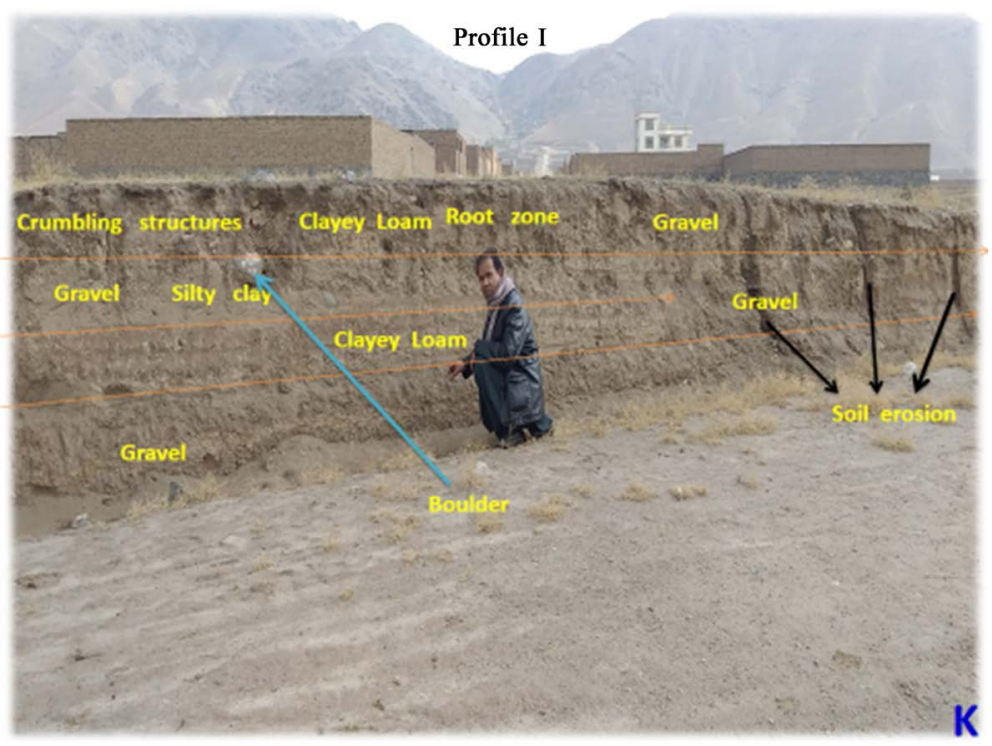

Figure 9. Profile I in Chelsaton sedimentary basin. 


\section{Profile II}

The profile II is different from profile I and there is Platy soil structure because the soil formation is gravels, the soil porosity and permeability is highly at the cold seasons. The soil layers freeing to more depth in the small size we can find platy structures. In this profile we can see different sizes like pebble, granule, sand and silt. From hydrometer analysis we found soil clayey loam (Figure 10).

\section{Granulometric Analysis}

Granulometric analysis has been carried out to know the content of sand, silt and clay (\%) in the present sediments. Percentage of sand, silt and clay (\%) content of the samples are presented in Figure 11. Sand is the main constituent in all the sampling locations. Silt content is the least constituent which varied. In

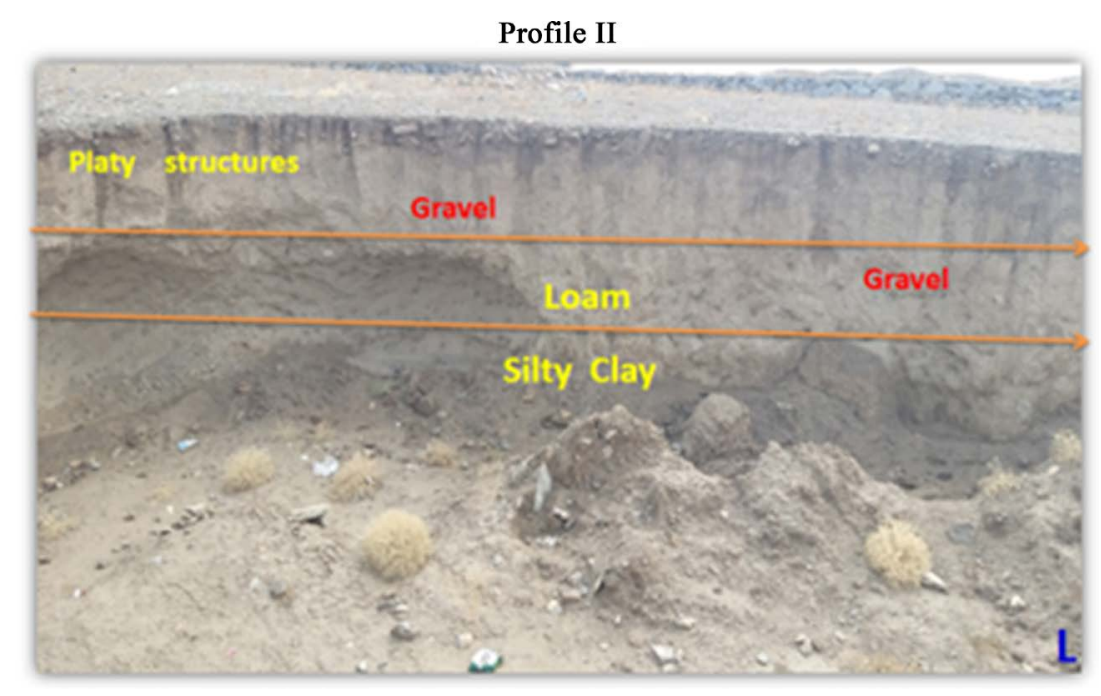

Figure 10. Profile II in Chelsaton sedimentary basin.

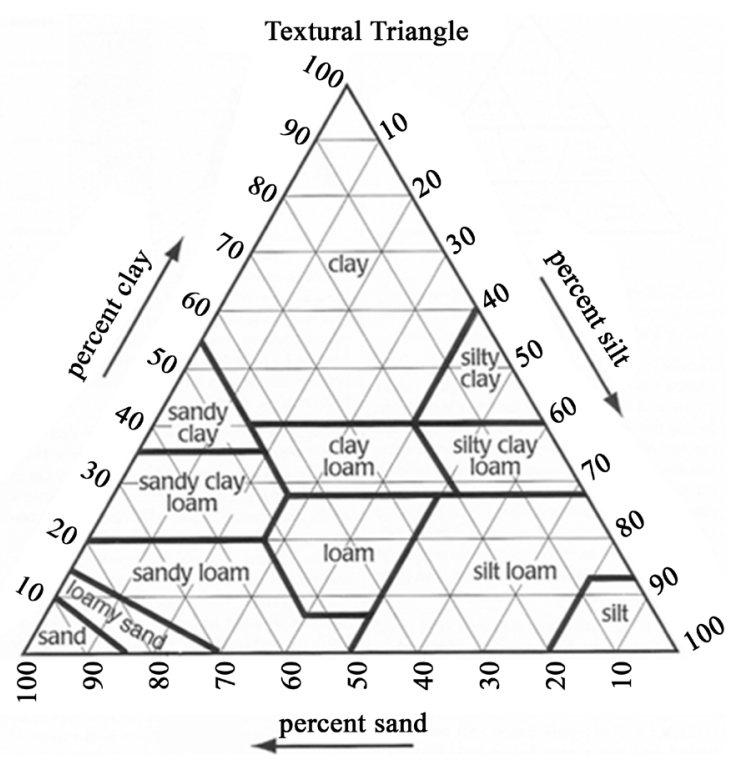

Figure 11. Textural triangle of the soil fractions (\%) in the soil profiles I and II [26]. 
the samples studied, particle sizes occur predominantly in a given sample, the heavy minerals are primarily finer grained than the average grain size of the whole sample (Figure 11).

\section{Hydrometer Analysis from Profile I and Profile II}

One part of this research is hydrometer analysis to find different percentage of soil fractions (sand, silt and clay), also called fine materials of soil. The percentage we found from the above triangle, from percentage of profile I and II different percentage of sand, silt and clay. In profile I we can see more percentage of sand after silt and smaller percentage is clay and the type of soil is loam and silt loam, but in the profile II the type of soil is loam and silt loam (Figure 12).

\section{Soil Profile III}

We can find different type of gravels like boulder, cobble, pebbles, granules, sands and silts. In this profile we generally can see two layers and there is not any graded bedding. Profile A consists of different sizes and more are angular. They are transported by high velocity, in ancient times will be turbulent streams. In layer B there are smaller gravels like pebble, granule, sand and silt. It will be low velocity of streams. As well as, in this profile we also can see angular unconformity (Figure 13). When we did sieving analysis in this profile from cumulative curve and Histogram we can find different sizes of materials (Figure 14).

\section{Sieving Analysis at Soil Profile III}

We can find different type of gravels like boulder, cobble, pebbles, granules, sands and silts. In this profile we generally can see two layers and there is not any graded bedding. Profile A consists of different sizes and more are angular. They are transported by high velocity, in ancient times will be turbulent streams. In layer B there are smaller gravels like pebble, granule, sand and silt. It will be

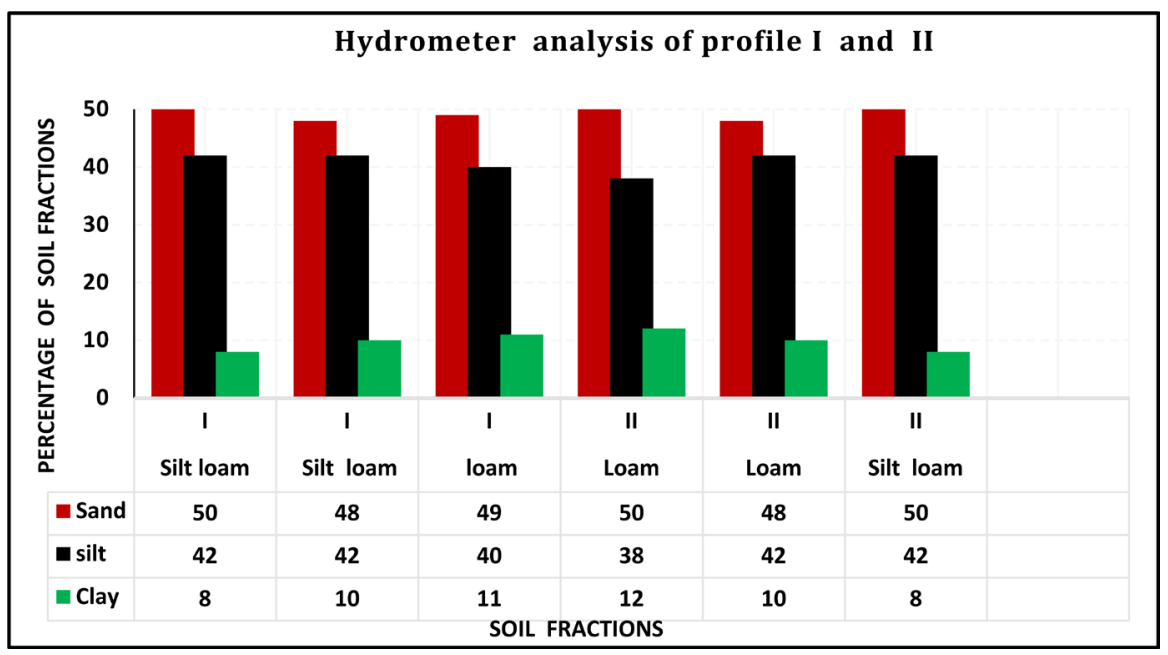

Figure 12. soil fractions percentage and soil types in profile I and II in Chelsaton sedimentary basin. 


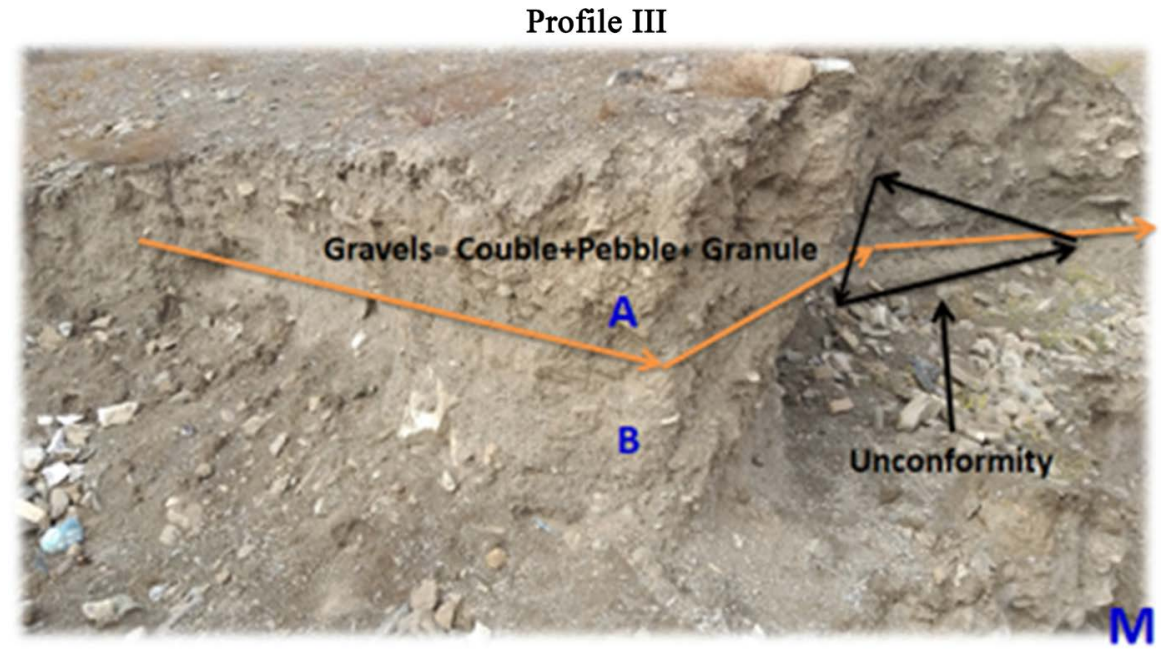

Figure 13. M. Profile III in Chelsaton sedimentary basin.

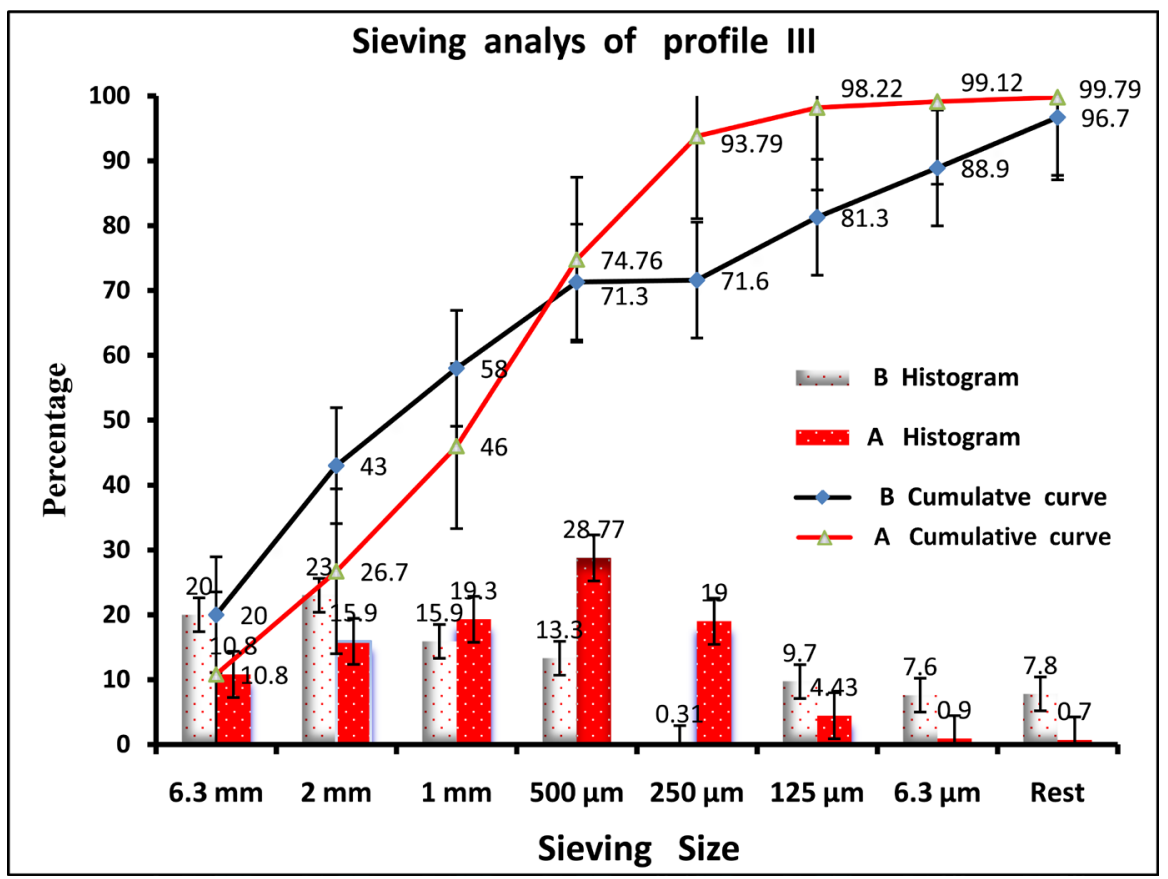

Figure 14. Cumulative curves and Histogram of profile III in Chelsaton sedimentary basin.

low velocity of streams. As well as, in this profile we also can see angular unconformity (Figure 13). When we done sieving analysis in this profile from cumulative curve and Histogram we can find different sizes of materials (Figure 14)

\section{Stratigraphy from Well Sampling}

In this research, we find stratigraphy up to $200 \mathrm{~m}$, from well sampling there are different layers at stratigraphy, there were different types of layers like sand, Bolder, gravel, Silty sand, Sand, Clay with gravel, Clay, Clay with gravel, Clay, silt with gravel (Figure 15). From water's point of view, in ground water there are some aquifers for ground water storage like gravel, Bolder, sand. 


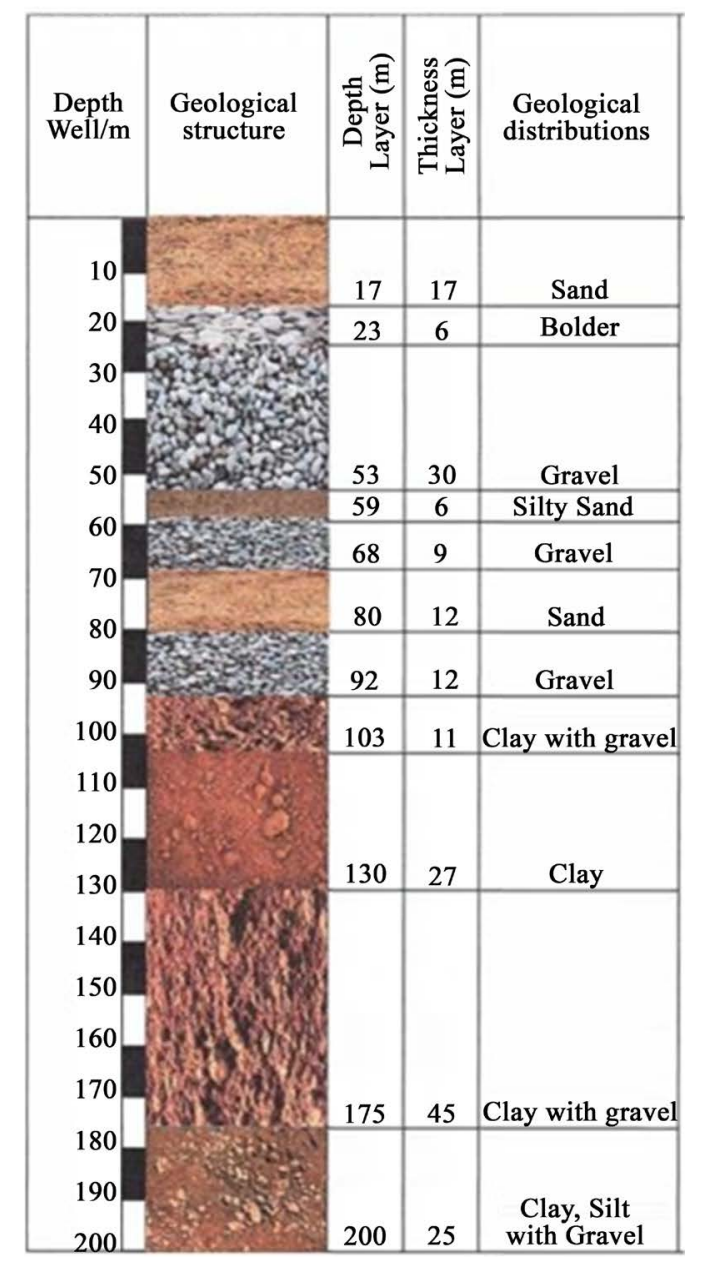

Figure 15. Well stratigraphy at the Chelsaton Sedimentary basin.

\section{Geological Mapping in Chelsaton Mountains Range}

The surrounding mountains of Chelsaton sedimentary basin have very complex tectonics, because there are more joints, cracks, faults, synclines, bedding planes, fracture, foliation, dyke, folds and the layers of rocks having different directions of strikes and dips (Figure 15). Likewise, there is fault breccia and millonite, the surface of layers are about $45^{\circ}$ angle with horizontal surface. Some places the strikes of layers are from northeast to southwest, but in other places the strike of layers are from west north to south north, in these mountains area we can see different types of synclinal valleys [27]. These types of mountains are fold-fault Mountains [28] (Figure 18). When we done some measurements of compass there is one anticline that weathered at the ancient times (Figure 18). In this research, for compass using we used four geographical directions (Figure 16 and Figure 17). In this mountain area the angle of dip is different at the different locations (Figure 18).

\section{Geographical Directions}

The geographical directions are the important parts of geology because of 
stricke, dip and layer surfaces that belong to geographical locations. In compass measurements we must know about four directions (Figure 16). In this research, we find the stricke of layer, there is the stricks of layer north to south, northeast to southwest and east to west (Figure 17).

\section{Tectonic Structures}

The Chelsaton Mountains have very complex tectonic. There are different tectonics structures of fold, faults, Joints, cracks and different types of valleys like diagonal, synclinal. From petrography point of view, the type of rocks is gneiss, slate and the kind of mountain is Fold-fault mountains. The angle of dip is about $45^{\circ}$ but in some places it is $15^{\circ}$. Besides, there are some signs of fault breccia and fault millonite (Figure 17).

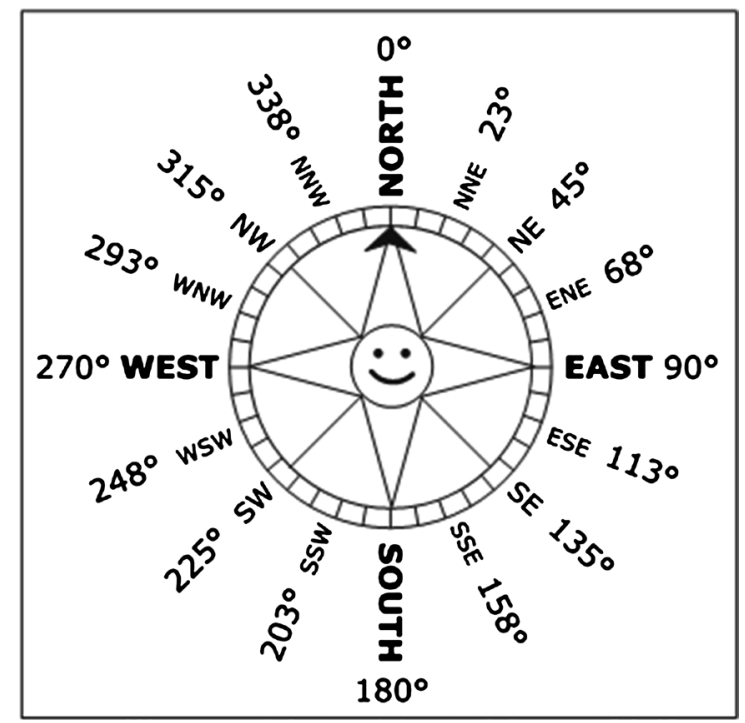

Figure 16. Four geographical directions for compass using [29].

The mountains having very Complex Tectonic

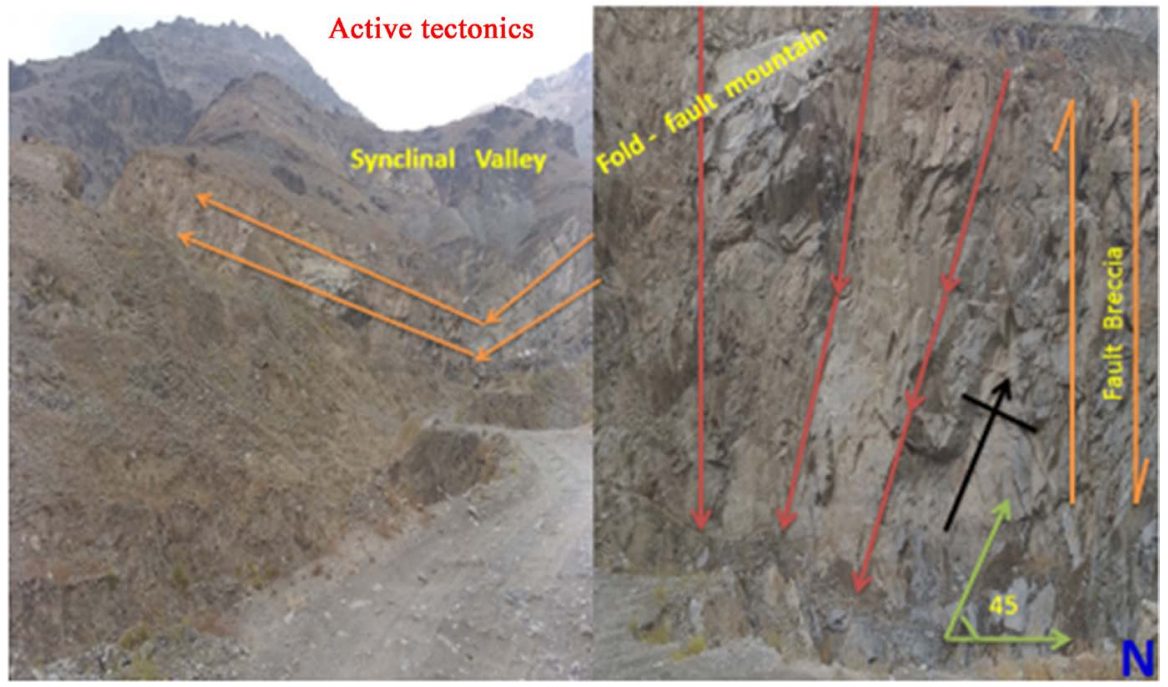

Figure 17. Geological mapping in Chelsaton Mountains. 


\section{Schematic Anticline}

From six compass measurement, we found the erosion schematic parts of anticline. So, at the previous geological periods there was completely anticline and it is incompletely anticline. Now, there are only two limbs of anticline and the crust and apex are weathered by different factors of exogenic forces. This erosion part belongs to the gneisses that is called the crystalline of Kabul. There are diverse layers at the different thickness, the angle of dip is different strike and is generally in southwest to northeast and southeast to northwest (Figure 18).

\section{Type of Folds}

As all know, most of the surrounding mountains of Kabul Sedimentary Basin are metamorphic rocks from gneisses type. They belong to Precambrian and called crystalline of Kabul. The Chelsaton Mountains have the same gneisses, in this research, among these rocks we found different types of folds, like symmetrical and asymmetrical according to the axial plains. There are some kinds of normal, vergent, recumbent, napes, upright, horizontal inclined, plunging upright folds and having very complex tectonic of metamorphic rocks (gneisses) and we found different folding (Figure 19). The surrounding mountains of Chelsaton Sedimentary Basin are called Sheer Darwaza Series.

\section{Angle of Dip}

From six compass measurement, we find different angles of dips at the different layers. There are metamorphic rocks (geniesses). They are very complex tectonics, the angles of dip is very different because there is active tectonic activities. From that, we can find at the anciant geological periods, there were more deformation and tectonic activities (Epirogeny and Orogeny, convergent, divergent and transform) (Figure 20). As well as, there are the rock layers, different at the deformation, because some rocks having different characteristics of elstic, plastic

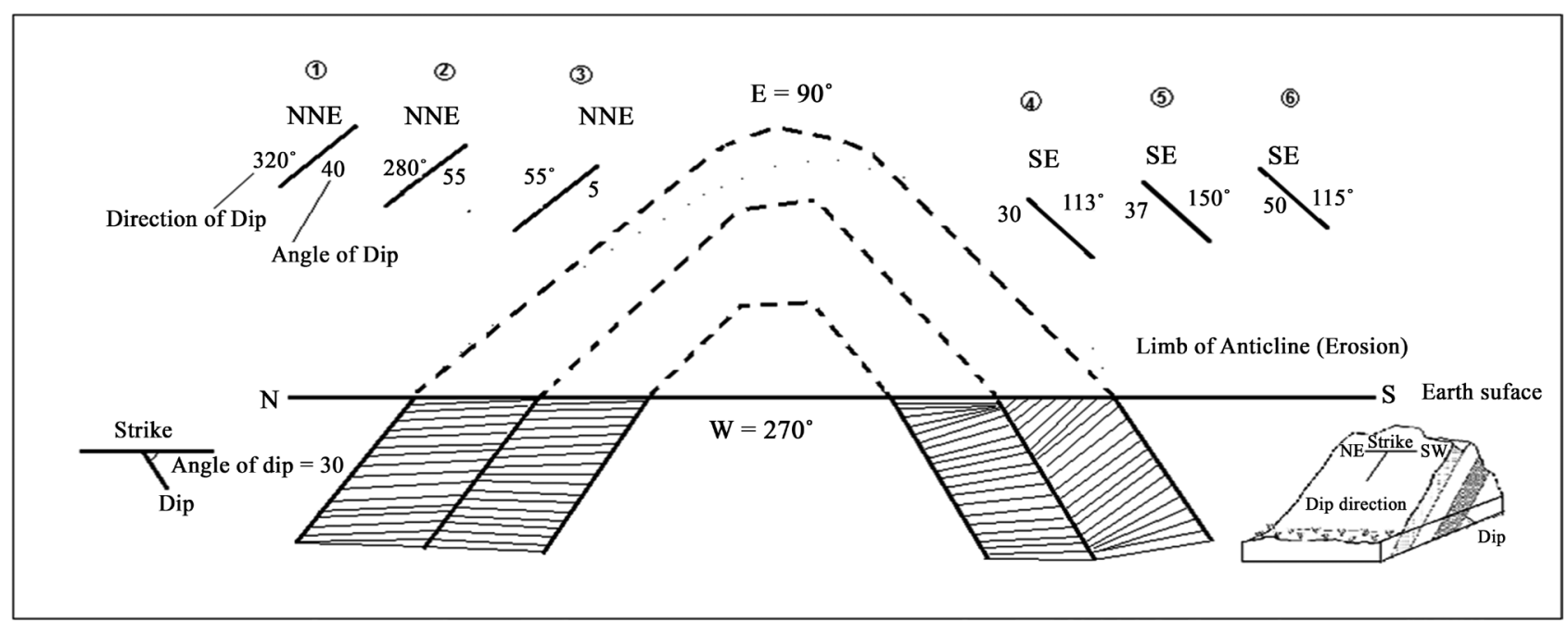

Figure 18. Some compass measurements and schematic anticline structure in Chelsaton Mountains. 


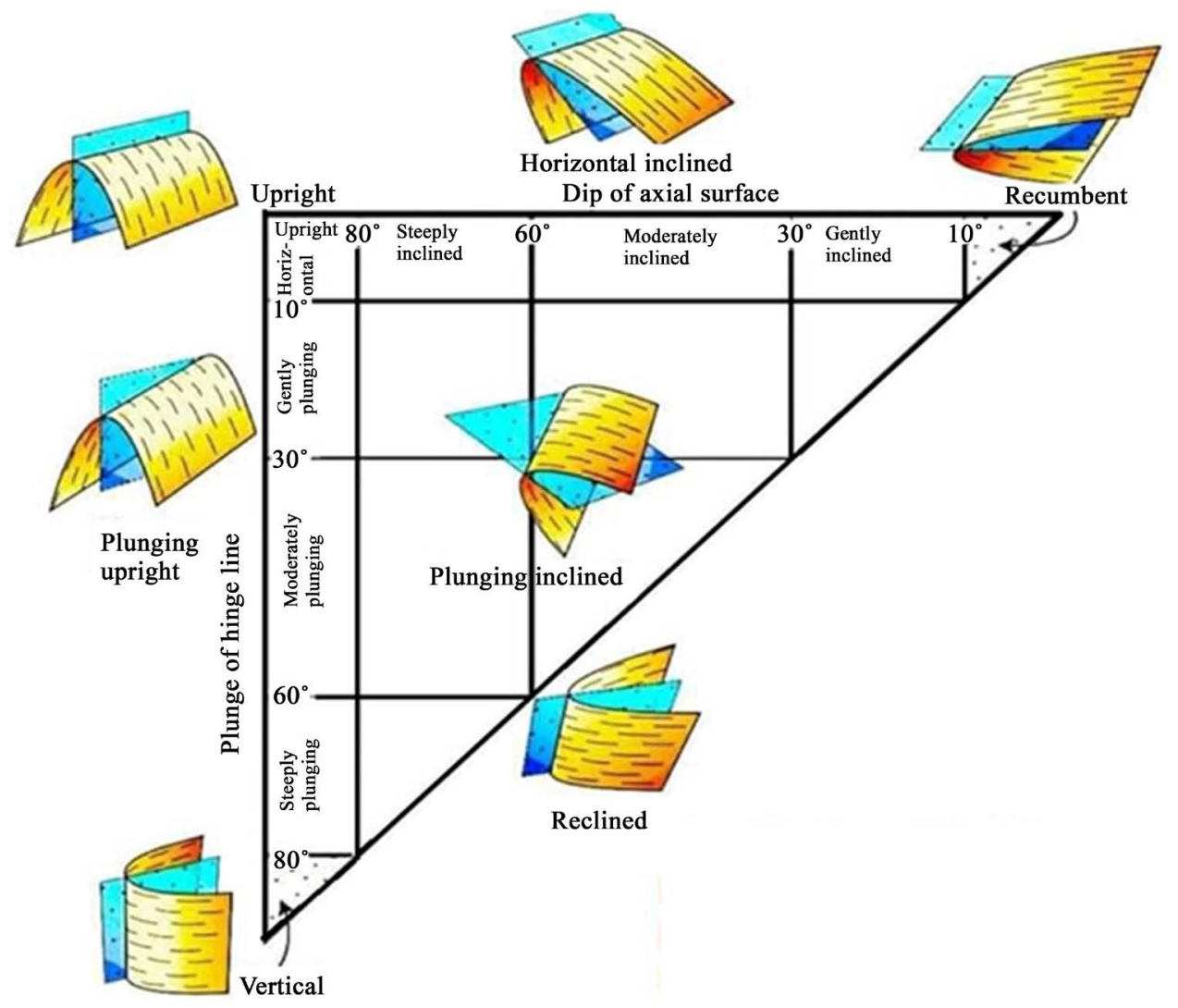

Figure 19. Different type of folds, based on orientation of hinging line and axial surface, in Chelsaton basin, surrounding mountains, Afghanistan [30].

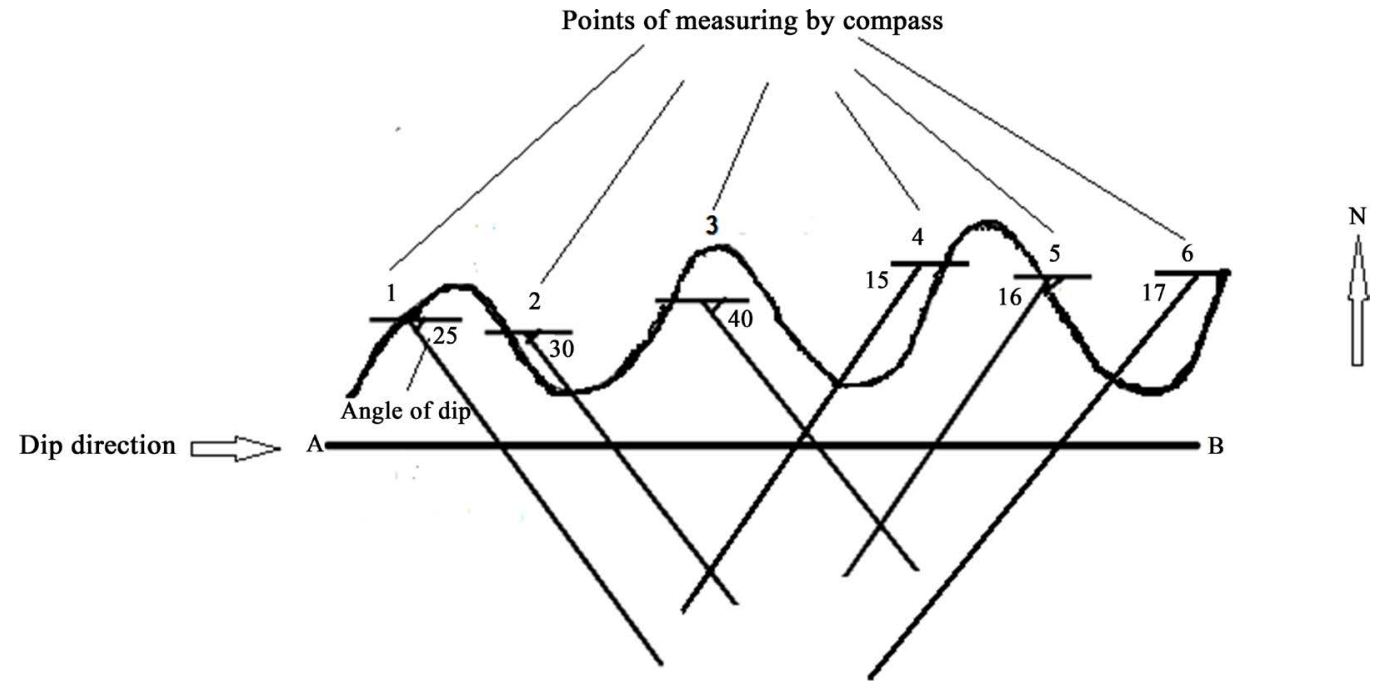

Figure 20. The determination of angle of dip by compass and dip direction in Chelsaton.

and rafture [31].

\section{Microscopic Studies of Joins and Cracks}

The tectonic of these mountains was very complex and there are different types of faults, joints, fractures, bedding plans, the magnitude of faults, joins and 
cracks, we can see at the (Figure 21). In this figure, the microscopy of faults, cracks and joints are at the different directions and some faults, cracks and joints are crossed by one another, from that view point we can find the age. There are different ages, from pre -historical periods to now there active tectonic activities (Figure 21).

\section{Faults Surface}

There are different directions of faults surface at the different angles, as well as there are slicken sides, faults breccia, faults millonite (Figure 22). It is clear that

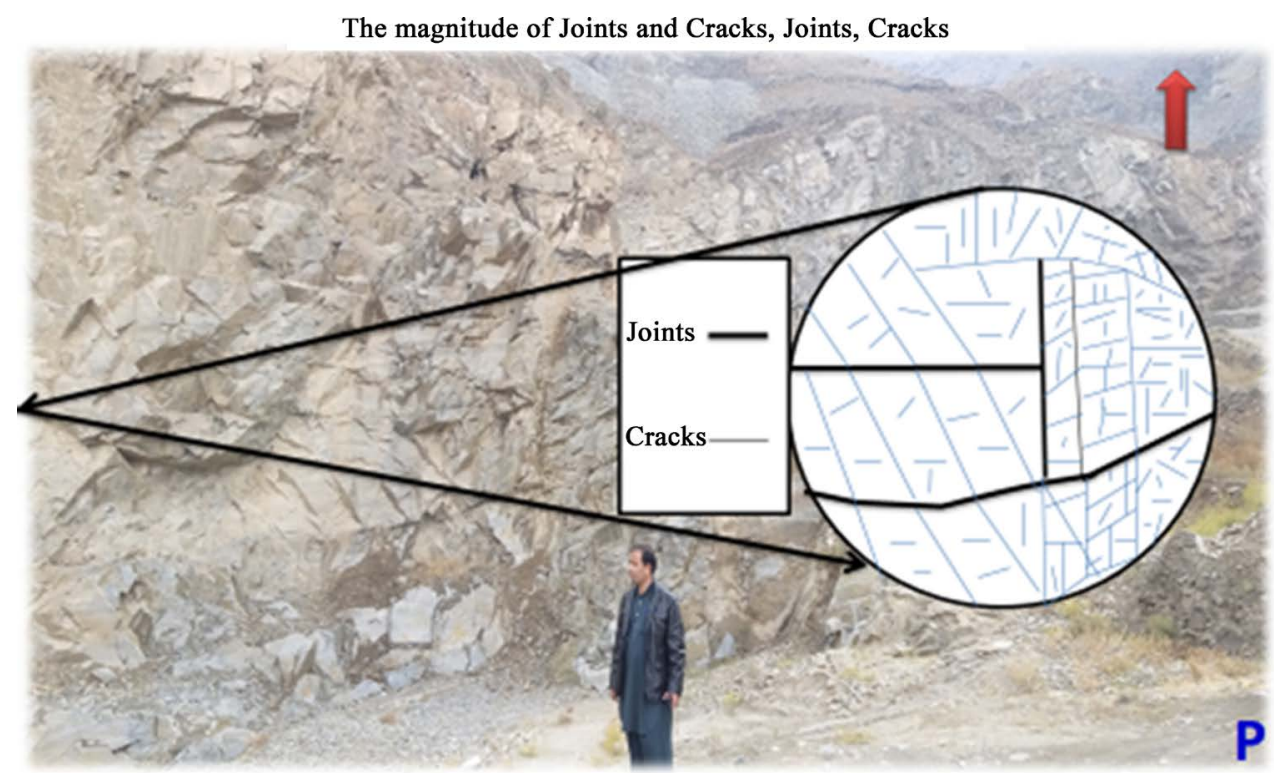

Figure 21. The magnitude of faults, joints and fractures in Chelsaton Mountains.

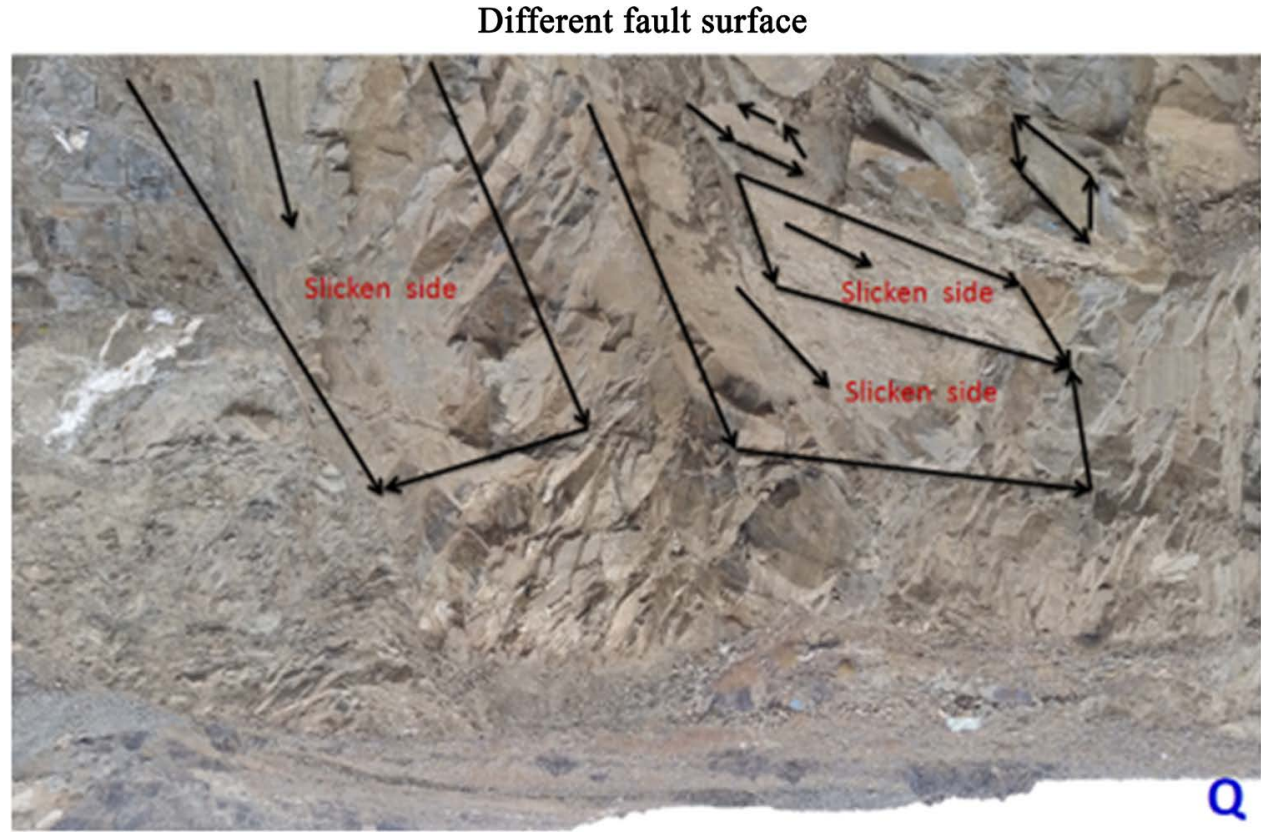

Figure 22. Different fault surface in Chelsaton Mountains. 
we can find the movement from north east to south west. From this figure, we can find different ages of faults surface and for next time there will be other movements of faults for next too.

\section{Layers, Strike and Dip}

The strike and dip between layers is different, generally the strike of layers is southwest to northeast (Figure 23), and due to complex tectonic activities and angle of dip being $10^{\circ}, 49^{\circ}, 45^{\circ}, 30^{\circ}, 40^{\circ}, 35^{\circ}, 65^{\circ}, 67^{\circ}$ and $75^{\circ}$ different.

According to axial plain in Chelsaton Mountain range, we can find different types of folds cylindrical, non-cylindrical, vergent, these folds have been constructed from complex tectonic activities. In this research, we found the different types of fold elements, in this mountain area according to the tectonic activities at the primordial geological periods [33], there is sign of different elements like; hinge line, hinge zone, fold axis, hinge point, hinge trace, inflection point, inflection line, limb, amplitude, inter limb angle (Figure 24 and Figure 25).
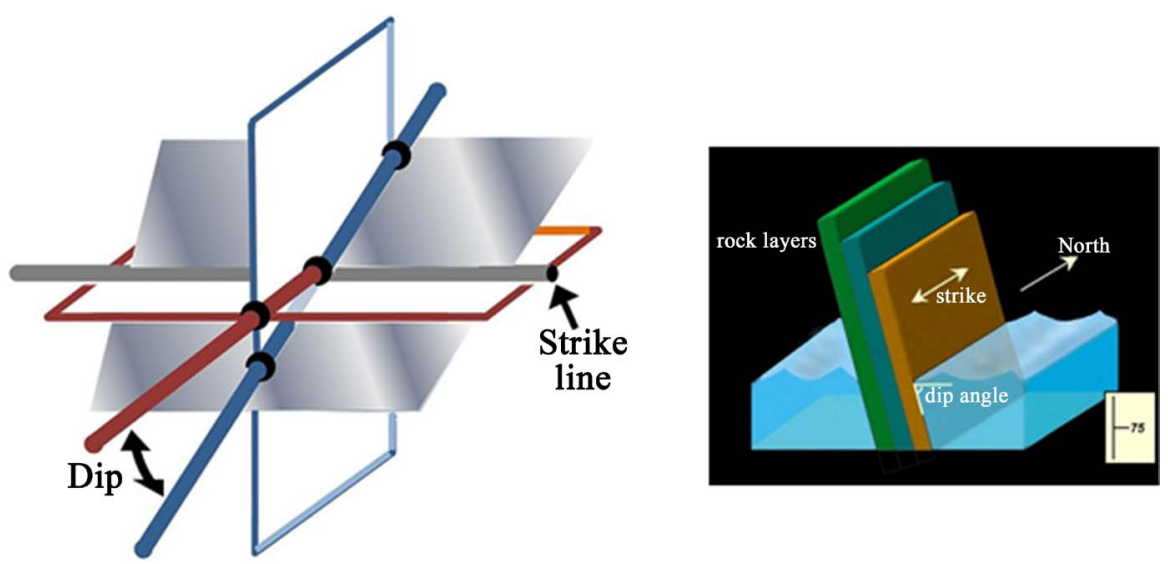

Figure 23. Shows the schematic dip and strike line and layers of different rocks in Chelsaton mountain range [32].

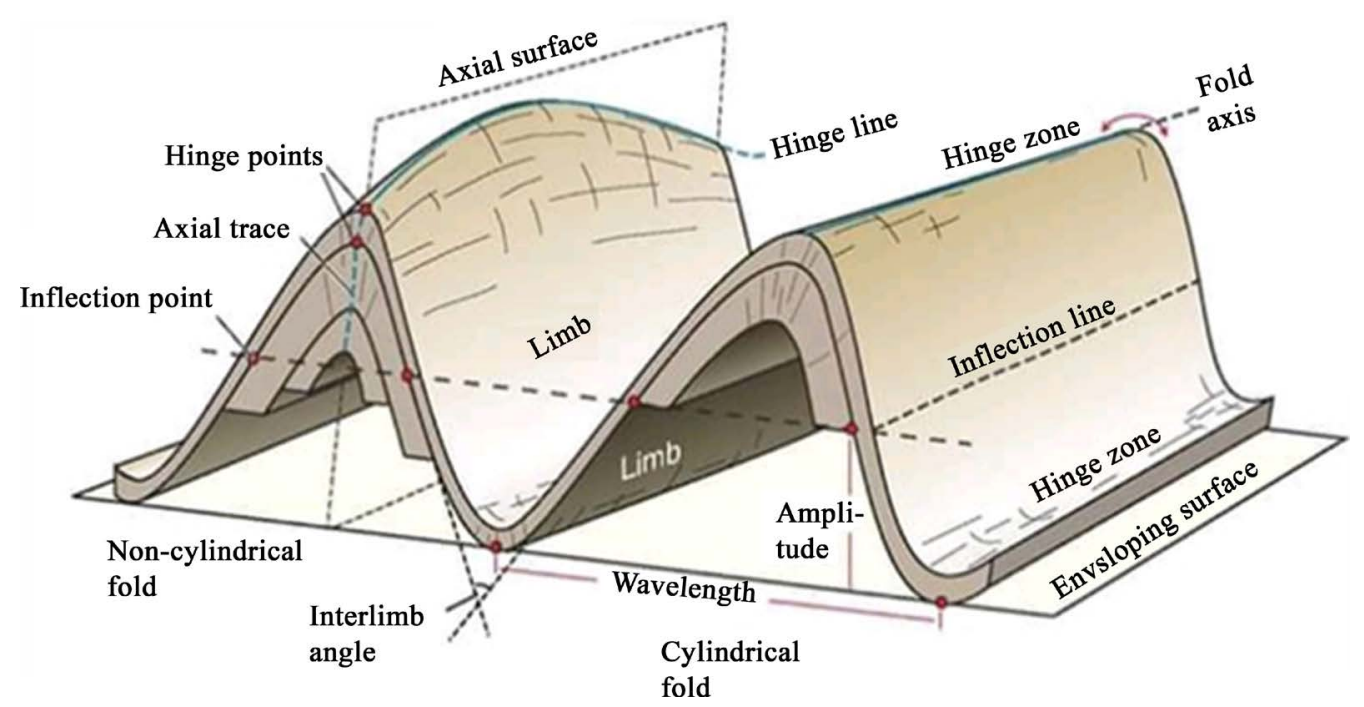

Figure 24. Normal fold and its elements in the Chelsaton mountains Gneiss [34]. 

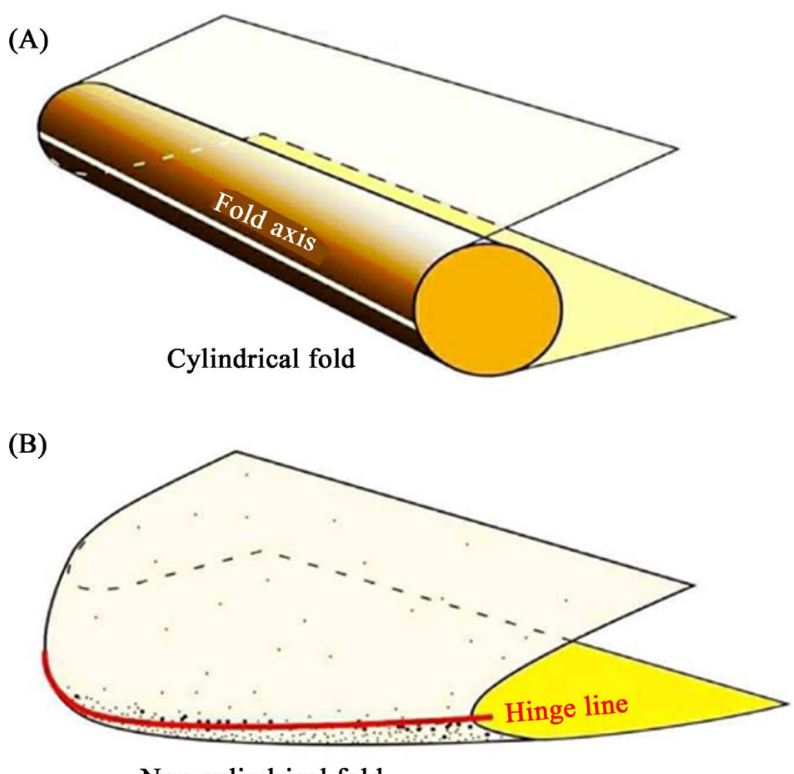

Non-cylindrical fold

Figure 25. Cylindrical and non-cylindrical folds in Chelsaton Mountain Gneisses [35].

\section{The Process of Metamorphism}

In Chelsaton Mountain range different types of metamorphic rocks change to one another. They consist of shale, slate, phyllite, schist, Gneiss, sandstones, quartzite, granite, metasandstone, greenschist and marble. They belong to the age, depth of metamorphism and type of materials, as shown in (Figure 26).

\section{Conclusion}

In the surrounding mountains we found different types of metamorphic rocks gneiss, schist's. For example, low grade and medium grade metamorphism Garnete mica schist, Garnete Schist, Quarsite. In these rocks we found different types of minerals Garnete, micas, from sediments different sizes of Garnete, Gneiss, Schist, Quarsite, Biotite and different sizes of sediments boulders, Cobble, Granule, Sand, Silt. There are different types of alluvial fans and Gully's, valleys, dry river terraces [37]. When we analyzed the soil samples, we found different types of Clayey loam, sandy loam, silty loam and different structures like Crumbling, Platy structures and from sieving analysis we found cumulative curves and Histograms. There are very complex tectonic structures of joints, cracks, faults, fault surface, millonite, fault breccia, Slicken side, and anticline syncline and the layers of rocks having different strikes and dips. All the regolith and sediments are transported from different points of Loger, Asmayey Mountains by sudden floods and Kabul River accumulated in different thickness at the different locations of this basin [38]. Types of sediments in this basin directly belong to the kinds of rocks. They are located in surrounding mountains. In these sediments, we can see Garnete, Biotite and Muscovite minerals. The surrounding mountains of this basin are formed from metamorphic rocks like Schist, Gneiss, Slate which is called Crystalline of Kabul. They belong to Precam 


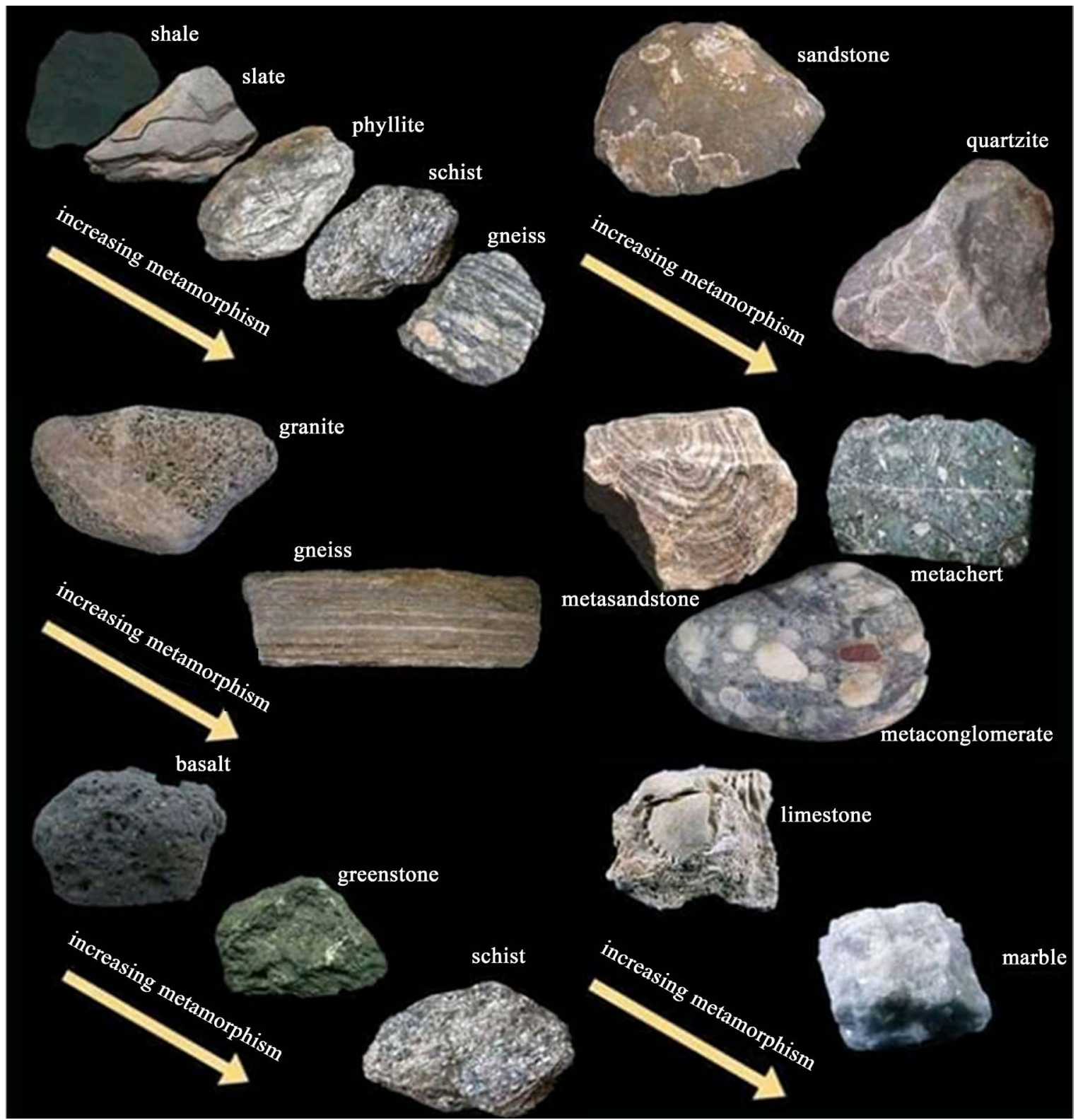

Figure 26. In this figure shows the different type of metamorphism in Chelsaton mountain range [36].

Brian (20 - 40 million years ago) [39]. When we did the gravel analysis there was more than Quartzite, Gneiss and Schist in these sediments. The relief of Chelsaton related to three kinds of relief. It consists of high (upper course) that belongs to slop mountains, middle relief (middle course), belongs to hills and plains areas (lower course), related to agricultural lands. Chelsaton Basin is located between mountains ranges which is called inter mountains backing basin. In plain areas passing Kabul River, the two laterals located at agricultural lands [40]. The Chelsaton Basin sediments belong to Quaternary (Pleistocene) [41] [42]. Sediments are transported from Paghman, Loger, Asmayie, Qorugh and Paghman Mountains. Chelsaton Sedimentary Basin is one of the inter mountain backing basins. In this basin, the size of sediments related to the near and away 
from mountains range, when we get close to the mountains the size sediments are getting bigger and angular. When the distance gets far from mountains, the sizes of sediments are getting smaller and angular. At the close areas of mountains we can find Boulder, Cobble, Pebble, granule. Nevertheless, in lower and plain areas we can see fine materials like sand, silt and clay. The results obtained suggest that further research should be done on topics such as soil physical and chemical properties by different laboratory tests, detail another sedimentological, geochemical, engineering geology, hydrogeology, hydrology, petrography, tectonic and geological mapping. Furthermore, the sedimentological research can be used efficiently in the other catchments of basin and other mountain basins in Afghanistan. At the end, we would request international organizations to promote research programs in above areas.

\section{Acknowledgements}

We would like to express our warm gratitude to anonymous referees for their valuable comments. I extend my thanks to our faculty members who helped us put this paper together.

\section{Conflicts of Interest}

The authors declare no conflicts of interest regarding the publication of this paper.

\section{References}

[1] Aldrich, M.L. (1979) American State Geological Surveys, 1820-1845. In: Schneer, C.J., Ed., Two Hundred Year of Geology in America, University Press of New England, Hanover, 133-143.

[2] Amundson, R. and Yaalon, D.H. (1995) E. W. Hilgard and John Wesley Powell: Efforts for a Joint Agricultural and Geological Survey. Soil Science Society of America Journal, 59, 4-13. https://doi.org/10.2136/sssaj1995.03615995005900010001x

[3] Anderson, J.A.R. (1999) The Structure and Development of the Peat Swamps of Sarawak and Brunei. Journal of Tropics Geography, 18, 7-16.

[4] Coe, A.L., Bosence, D.W.J., Church, K.D., Flint, S.S., Howell, J.A. and Wilson, R.C.L. (2003) The Sedimentary Records of Sea-Level Change. Cambridge University Press, Cambridge, 46.

[5] Anthony, E.J. and Héquette, A. (2007) The Grain-Size Characterization of Coastal Sand from the Somme Estuary to Belgium: Sediment Sorting Processes and Mixing in a tide-and Storm-Dominated Setting. Sedimentary Geology, 202, 369-382. https://doi.org/10.1016/j.sedgeo.2007.03.022

[6] Ball, M.M. (1967) Carbonate Sand Bodies of Florida and Bahamas. Journal of Sedimentary Petrology, 37, 556-591. https://doi.org/10.1306/74D7171C-2B21-11D7-8648000102C1865D

[7] Bentley, S.J., Sheremet, A. and Jaeger, J.M. (2006) Event Sedimentation, Bioturbation, and Preserved Sedimentary Fabric: Field and Model Comparisons in Three Contrasting Marine Settings. Continental Shelf Research, 26, 2108-2124.

https://doi.org/10.1016/j.csr.2006.07.003 
[8] Bloom, P.R., Skyllberg, U.L. and Summer, M.E. (2005) Soil Acidity. In: Tabatanai, A. and Sparks, D., Eds., Chemical Processes in Soils, Vol. 8., Soil Science Society of America, Madison, 411-459. https://doi.org/10.2136/sssabookser8.c8

[9] Bochm, W. and Van der Ploege, R.R. (2004) Julius Adolf Stoeckardt (1809-1886), Pioneer in Agricultural Brevik, Chemistry, Soil Science Society of America Meeting Abstracts. Published on CD-ROM, 165. [Discusses the Career of the First Extension Faculty Member]

[10] Brevik, E.C. (2004) Contributions of Edward Elway Free to American Soil Science in the Early 1900s. Soil Science Society of America Journal, 68, 904-905. https://doi.org/10.2136/sssaj2004.9040

[11] Colella, A and di Geronimo, I. (1998) Surface Sediments and Macro Fanas of the Grati Submarine Fan (Ionian Sea, Italy) Sedimentary Geology. p. 77.

[12] Elliott, T. (1999) Deltas. In: Reading, H.G., Ed., Sedimentary Environments and Facies, 2nd Edition, Blackwell Scientific Publications, Oxford, 113-154.

[13] Elliontt, T. (2001) Siliciclasstic Shorlines Sedimentary Environments and Facies. 2nd Edition, Blackwell Scientific Publications, Oxford, 85.

[14] Folk, R.L. (2004) Spectral Divission of Limestone Types. In: Ham, W.E., Ed., Classification of carbonate Rocks, Memoirs of the American Association of Petroleum Geology, Tulsa, 62-84.

[15] Feller, C., Brown, G.G., Blanchart, E., Deleporte, P. and Chernyanskii, S.S. (2003) Charles Darwin, Earthworms, and the Natural Science, Variation Lessons from Past to Future. Agriculture, Ecosystems \& Environment, 99, 29-49. https://doi.org/10.1016/S0167-8809(03)00143-9

[16] Goff, J., McFadgen, B. and Chagué-Goff, C. (2004) Sedimentary Differences between the 2002 Easter Storm and the 15th Century Okoropunga Tsunami, Southeastern North Island, New Zealand. Marine Geology, 204, 235-250. https://doi.org/10.1016/S0025-3227(03)00352-9

[17] González-Álvarez, R., et al. (2005) Paleoclimatic Evolution of the Galician Continental Shelf (NW of Spain) during the Last 3000 Years: From a Storm Regime to Present Conditions. Journal of Marine Systems, 54, 245-256.

https://doi.org/10.1016/j.jmarsys.2004.07.015

[18] Heidt, C.J. (2004) Soils and Landforms Related to Observations Madw by the Lewis and Calark Expeditons in North Dakota. Soil Seienee Socity of Amerca Meeting Abstracts. Published on CD-ROM, p. 33.

[19] Helms, D. (2002) Early Leaders of the Soil Survey. In: Helms, D., Effland, A.B.W. and Durana, P.J., Eds., Profiles in the History of the U.S. Soil Surevy, Lowa State University Press, Ames, 19-64. https://doi.org/10.1002/9780470376959.ch2

[20] Herman, E.K., Toran, L. and, White W.B. (2009) Quantifying the Place of Karst Aquifers in the Groundwater to Surface Water Continuum: A Time Series Analysis Study of Storm Behavior in Pennsylvania Water Resources. Journal of Hydrology, 376, 316-317. https://doi.org/10.1016/j.jhydrol.2009.07.043

[21] Horikawa, K. and Ito, M. (2009) Non-Uniform across-Shelf Variations in Thickness, Grain Size, and Frequency of Turbidities' in a Transgressive Outer-Shelf, the Middle Pleistocene Kakinokidai Formation, Boso Peninsula, Japan. Sedimentary Geology, 220, 105-115. https://doi.org/10.1016/j.sedgeo.2009.07.002

[22] Kortekaas, S. and Dawson, A. (2007) Distinguishing Tsunami and Storm Deposits: An Example from Martinhal, SW Portugal. Sedimentary Geology, 200, 208-210. https://doi.org/10.1016/j.sedgeo.2007.01.004 
[23] Krupenikov, I.A. (1992) History of Soil Science, from its Inception to the Presem. Amerind Publishing Co., New Delhi, 352 p.

[24] Idrisi, Z. (2005) The Muslim Agricultural Revolution and its Influence on Europe. Foundation for Science Technology and Civilisation. FSTC Ltd., Manchester, 19 p.

[25] Leeder, M. (2006) Sedimentology and Sedimentary Basins. Grphicraft, Ltd, Hong Kong, Replika Press Pvt. Ltd., Kundli, 193.

[26] Morton, R.A., Gelfenbaum, G. and Jaffe, B.E. (2007) Physical Criteria for Distinguishing Sandy Tsunami and Storm Deposits Using Modern Examples. Sedimentary Geology, 200, 184-207. https://doi.org/10.1016/j.sedgeo.2007.01.003

[27] Krishna, R. and Poudel, R. (2015) A Textbook of Soil Mechanics. Heritage Publications, Bhotahity, 6-10.

[28] Kumar Dahal, R. (2006) Geology for Technical Students. Department of Geology, Tri- Chandra Multiple Campus, Kathmandu, 23.

[29] Rasouli, H., Sarwari, M.H., Rasikh, K. and Hashimi, S.A. (2020) Geological Study of Tangi Mahi-Par Mountain Range along Kabul Jalalabad Road, Afghanistan. Open Journal of Geology, 10, 971-980. https://doi.org/10.4236/ojg.2020.1010044

[30] Rasouli, H. (2020) Application of Soil Physical and Chemical Parameters and Its Comparing in Kabul Sedimentary Basins, Kabul, Afghanistan. International Journal of Scientific Research, 11, 37368-37380.

[31] Rasouli, H. (2017) Study on River Terraces in Upper and Middle Parts of Kabul Sedimentary Basin, Afghanistan. International Journal of Science and of Research, 6, 1696-1704.

[32] Rawoofi, F. (2003) General Geology. Geosciences Faculty, Kabul University, Kabul, 39.

[33] Rubin, D.M. (2004) A Simple Autocorrelation Algorithm for Determining Grain Size from Digital Images of Sediment. Journal of Sedimentary Research, 74, 160-165. http://dx.doi.org/10.1306/052203740160

[34] Ruleman, C.A., Crone, A.J., Machette, M.N., Haller, K.M. and Rukstales, K.S. (2007) Map and Database of Probable and Possible Quaternary Faults in Afghanistan. United States Geological Survey, Reston, 39 p. https://doi.org/10.3133/ofr20071103

[35] Sahak, N. (2012) Geology of Afghanistan. Polytechnics University, Kabul.

[36] Sedgwick, P.E. and Davis, R.A. (2003) Stratigraphy of Washover Deposits in Florida: Implications for Recognition in the Stratigraphic Record. Marine Geology, 200, 31-48. https://doi.org/10.1016/S0025-3227(03)00163-4

[37] Sun, Y., Gao, S. and Li, J. (2003) Preliminary Analysis of Grain-Size Populations with Environmentally Sensitive Terrigenous Components in Marginal Sea Setting. Chinese Science Bulletin, 48, 184-187. https://doi.org/10.1360/03tb9038

[38] Tang, X., Chen, M., Liu, J., Zhang, L. and Chen, Z. (2004) The Anisotropy of Magnetic Susceptibility of Core NS97-13 Sediments from the Nansha Islands Sea Area in the Southern South China Sea. Acta Oceanologica Sinica, 31, 69-70 (in Chinses with English Abstract).

[39] Zarif, T.M. (2010) General Geography of Afghanistan, Kabul University, Kabul, Afghanistan, 87.

[40] Tuttle, M.P., Ruffman, A., Anderson, T. and Jeter, H. (2004): Distinguishing Tsunami from Storm Deposits in Eastern North America: The 1929 Grand Banks Tsunami versus the 1991 Halloween Storm. Seismological Research Letters, 75, 117-131. https://doi.org/10.1785/gssrl.75.1.117 
[41] Ven Baren, H., Hartemink, A.E. and Tinker, P.B. (2000) 75 Years of The International Society of Soil Science. Geoderma, 96, 1-18.

https://doi.org/10.1016/S0016-7061(99)00097-X

[42] Xiao, S., Liu, W., Li, A., Yang, S. and Lai, Z. (2009) Pervasive Autocorrelation of the Chemical Index of Alteration in Sedimentary Profiles and Its Palaeoenvironmental Implications. Sedimentology, 57, 670-676.

https://doi.org/10.1111/j.1365-3091.2009.01113.x 